\title{
Fall Acclimation and the Lift/Store Pathway: Effect on Reforestation
}

\author{
Steven C. Grossnickle ${ }^{*}, 1$ and David B. South ${ }^{2}$ \\ ${ }^{I}$ Nursery to Forest Solutions, Sidney, BC, CANADA \\ ${ }^{2}$ School of Forestry and Wildlife Sciences, Auburn University, AL 36849, USA
}

\begin{abstract}
This review compares fall acclimation patterns and lift/store practices for Pseudotsuga menziesii var. menziesii, Picea glauca (Moench) Voss x P. engelmannii Parry ex engelm and Pinus taeda L. seedlings. Spruce seedlings achieve budset and an endodormant state in late summer, coastal Douglas-fir in early fall, while loblolly pine achieves a less endodormant state with a limited amount of mitotic activity. Natural chilling during the fall reduces days to budbreak (DBB) and increases freezing tolerance, with northern species achieving greater freezing tolerance. Although root growth potential (RGP) in some years may increase from early fall to mid-winter, this trend does not always occur. Chilling hours and/or freezing tolerance status is used to initiate storage of Douglas-fir and spruce seedlings but there is no proven attribute to make the lifting decision for loblolly pine. When properly hardened, all species can be cooler stored to meet lift/store requirements of a few months, though fall lifted interior spruce seedlings are typically freezer stored for up to six months. Lengthy storage can cause declines in DBB, freezing tolerance, RGP, and carbohydrate reserves. Douglas-fir and interior spruce seedlings require an appropriate length of fall acclimation, typically including chilling, to develop a level of hardiness for lengthy storage and high survival after outplanting. Loblolly pine seedlings benefit from chilling, though non-chilled, hardened seedlings may exhibit high survival after four weeks of cooler storage. Each species has a unique fall acclimation pattern making it difficult to define universal culture practices across all regional forest regeneration programs.
\end{abstract}

Keywords: Bud dormancy, freezing tolerance, lifting practices, outplanting performance, root growth potential, seedling quality, storability.

\section{INTRODUCTION}

The effects of various cultural practices on seedling performance after transplanting need to be fully understood in order to make sound forest regeneration decisions. These cultural practices can be broadly grouped into three stages. The first stage is to produce seedlings with physiological and morphological attributes that improve the chances of successful field establishment [1-7]. The second stage involves lift/store practices that do not lower seedling quality as seedlings transition from the nursery to the field site [812]. The third stage covers silvicultural practices (e.g. handling, planting date, planting practices, site preparation, and vegetation management), all of which have an effect on establishment success [13-18]. If these stages are correctly implemented, transplanted seedlings initiate growth and become "coupled" into the forest ecosystem [19] with survival related to their inherent growth potential and the degree to which field site environmental conditions limit or enhance their field establishment [17].

The lift/store stage involves operational decisions of both nursery practitioners and regeneration silviculturists. It has

*Address correspondence to this author at the 1325 Readings Drive, Sidney, British Columbia, V8L 5K7 CANADA; Tel: 250-655-9155;

E-mail: sgrossnickle@shaw.ca long been recognized that lifting of seedlings in the fall and then storing under cold conditions are useful for holding seedlings until they are required at the planting site [20]. From these earlier times until the present, lift/store practices have been refined and general protocols have been defined for both bareroot $[13,21]$ and container-grown seedlings [12, 22]. However, operational steps of lift/store are different for each species and this should be recognized when making reforestation decisions. Assuming what works for one species works for all is flawed logic. Three distinctly different North American conifer species are examined; loblolly pine (Pinus taeda L.), coastal Douglas-fir (Pseudotsuga menziesii var. menziesii) and interior spruce (Picea glauca (Moench) Voss x P. engelmannii Parry ex engelm). These species come from different geographic regions and have differing nursery and silvicultural requirements. This provides an ideal opportunity to comprehensively discuss the lift/store pathway.

The lift/store stage of a forest regeneration program is examined in three phases: Phase one, the biological processes during fall acclimation; Phase two, physiological responses during the nursery practices of hardening, lifting and length of cold/frozen storage and; Phase three, the combined impacts of fall acclimation, nursery hardening practices and storage on seedling survival in the field. As aptly stated by Schubert and Adams [23] describing the 
criteria for successful storage: "...trees must be 1) lifted at the right time, 2) stored in the right way, and 3) stored under the right conditions." The objective of this review is to conduct a comprehensive examination of the published work on practices related to the lift/store pathway for loblolly pine, coastal Douglas-fir and interior spruce seedlings, and define how ecophysiological patterns for these species during fall acclimation and applied silvicultural practices affect seedling quality and success of forest regeneration programs.

\section{FALL ACCLIMATION}

Conifer seedlings become acclimated during the fall in response to chilling. Chilling hours are frequently used to quantify exposure to cold temperatures, though different temperature ranges have been used to define a chilling hour. In the southern US, chilling hours are typically reported within the range of 0 to $8{ }^{\circ} \mathrm{C}$ [24-27] and this range is used in all loblolly pine sections of this manuscript. In Canada, Washington and Oregon, chilling hours have included, in certain instances, all hours below freezing potentially increasing reported chilling hours by $1,000 \mathrm{~h}$ or more [28]. Studies in these regions have used maximum temperature values ranging from a low temperature of $4.4^{\circ} \mathrm{C}[29,30]$ to a higher one of $10{ }^{\circ} \mathrm{C}[28,31,32]$. A chilling unit (not equivalent to a chilling hour) might accumulate time within the range of -4 to $16{ }^{\circ} \mathrm{C}$ with different temperatures contributing values ranging from $1 \mathrm{~h}$ to $0.01 \mathrm{~h}$ [33]. When hourly data are not available, "chill days" [34] or "degreehardening-days" [12] or "hardening degree days" [35] are sometimes reported. Differences in quantification of chilling should be recognized when drawing general observations regarding specific chilling values.

Changes in phenological and physiological parameters during the fall occur in parallel during chilling, but these factors are not always linked [36, 37]. Root growth also varies throughout the growing season in temperate zone tree species [38-40]. General cyclical trends in these parameters describe the dynamic pattern of seasonal change that occurs in conifer species [40-42]. Implicit within this discussion is the recognition that genetic sources for each species can cause variability in their response during fall acclimation $[17,26,32]$.

After the summer solstice, day length shortens, promoting the development of vegetative maturity [36]. With northern conifers, the end of shoot elongation and development of over-winter terminal buds indicates vegetative maturity [41] and is considered to be the first stage of fall acclimation to low temperatures [43, 44]. Dormancy occurs "when an organ or tissue, predetermined to elongate or grow in some other manner, does not do so" [45]. In temperate tree species, use of the term "dormancy" should be restricted to the apical meristems [46]. During late summer and early fall, as bud dormancy intensifies, there may be an increase in the number of days to budbreak (DBB) [36]. When terminal buds are fully endodormant [47], they are unlikely to elongate until they are exposed to a period of cold temperatures [48]. As plants are exposed to fall cold temperatures they move towards a state of ecodormancy, with DBB decreasing [36, 41], stress tolerance increasing (i.e. freezing and drought tolerance); [17] and there may be an increase in root growth potential (RGP)
[42]. Temperate zone conifer species remain in an ecodormant state $[36,41]$; meaning they are ready to grow, but remain inactive only as long as environmental conditions are unfavorable for growth. The following discussion focuses on general patterns for each species during the fall as seedlings transition from an active growth phase until fully acclimated to winter conditions.

\section{Acclimation Patterns}

\section{Loblolly Pine}

Depending upon environmental factors, height growth of seedlings typically stops by late August (northern genotypes) or in September (southern genotypes) [26, 49]. Late spring sowing [50] and/or optimum cultural conditions can extend seedling height growth into the fall [51], though it can be curtailed by certain hardening practices [51]. Unlike most northern conifers, loblolly pine does not reach a fully endodormant state since the mitotic index of terminal buds does not reach zero [49]. Non-chilled seedlings typically resume height growth when placed under $14 \mathrm{~h}$ photoperiods [24] and some seed sources exhibit a maximum DBB value of less than 50 days [49]. Within most of the natural range, seedling diameter and root growth continue throughout the winter $[48,50,52]$. Thus, loblolly pine seedlings can exhibit radial growth throughout the fall and winter.

There are two schools of thought regarding timing of endodormancy (a.k.a. maximum DBB) for terminal buds of loblolly pine. Some researchers found that endodormancy peaks prior to any chilling (in late summer) and seedlings move towards a state of ecodormancy as chilling hours accumulate [24]; Fig. (1). With other genotypes, endodormancy peaks in late fall (Fig. 1) after some chilling has occurred $[49,53,54]$. This difference might be related to two factors. First, in the southern US, environmental conditions in the fall are quite variable with warm weather conditions sometimes persisting well into November with shoot growth cessation occurring sometime between August and November [51]. Second, genetic variation could affect initial phases of endodormancy with northern genotypes reaching a deeper state of endodormancy earlier in the year [53]. Regardless of which path seedlings adopt to reach a point of maximum $\mathrm{DBB}$, they move towards ecodormancy and reach their lowest DBB sometime after exposure to 600 or more chilling hours (Fig. 1).

Freezing tolerance of loblolly pine increases as chilling hours accumulate and move through the fall into mid-winter (Fig. 2). For container-grown seedlings, an $\mathrm{LT}_{50}$ of $-6.4{ }^{\circ} \mathrm{C}$ and $-13.6{ }^{\circ} \mathrm{C}\left(\mathrm{LT}_{50}\right.$ is the temperature lethal to $50 \%$ of the seedlings) was reported on November 21 and December 20, respectively [55] (Note: $-\mathrm{LT}_{50}$ and $\mathrm{EL}_{50}$ have been used to indicate the temperature at which there is $50 \%$ electrolyte leakage of needle tissue). Estimated chilling hours $\left(0-8{ }^{\circ} \mathrm{C}\right)$ on these dates were 160 and 520 hours, respectively. In addition to chilling, the maximum development of freezing tolerance depends on genotype $[56,57]$. Loblolly pine nursery managers need to know the genotypic variability within their crop before attempting to estimate freezing tolerance based on chilling accumulation.

Loblolly pine can have varying levels of RGP during the fall and winter. For bareroot seedlings, RGP can be higher in 
the fall than in early winter [58-60]. In contrast, RGP can be low in October with a peak in late February to early March [61]; Fig. (3). The assumption that RGP of container-grown and bareroot seedlings always increases from October to February led some to incorrectly assume that chilling was required for loblolly pine to have adequate RGP [59]. However, other studies demonstrate adequate RGP for October-lifted seedlings. For example, Freyman et al. [59] found that RGP in late October was as high as that in December or January, with the highest RGP occurring in November. Some genotypes had high RGP throughout the entire fall acclimation period and it persisted until late winter [26, 60]; Fig. (3). Thus, loblolly pine does not have a consistent pattern of root growth during the fall and winter.
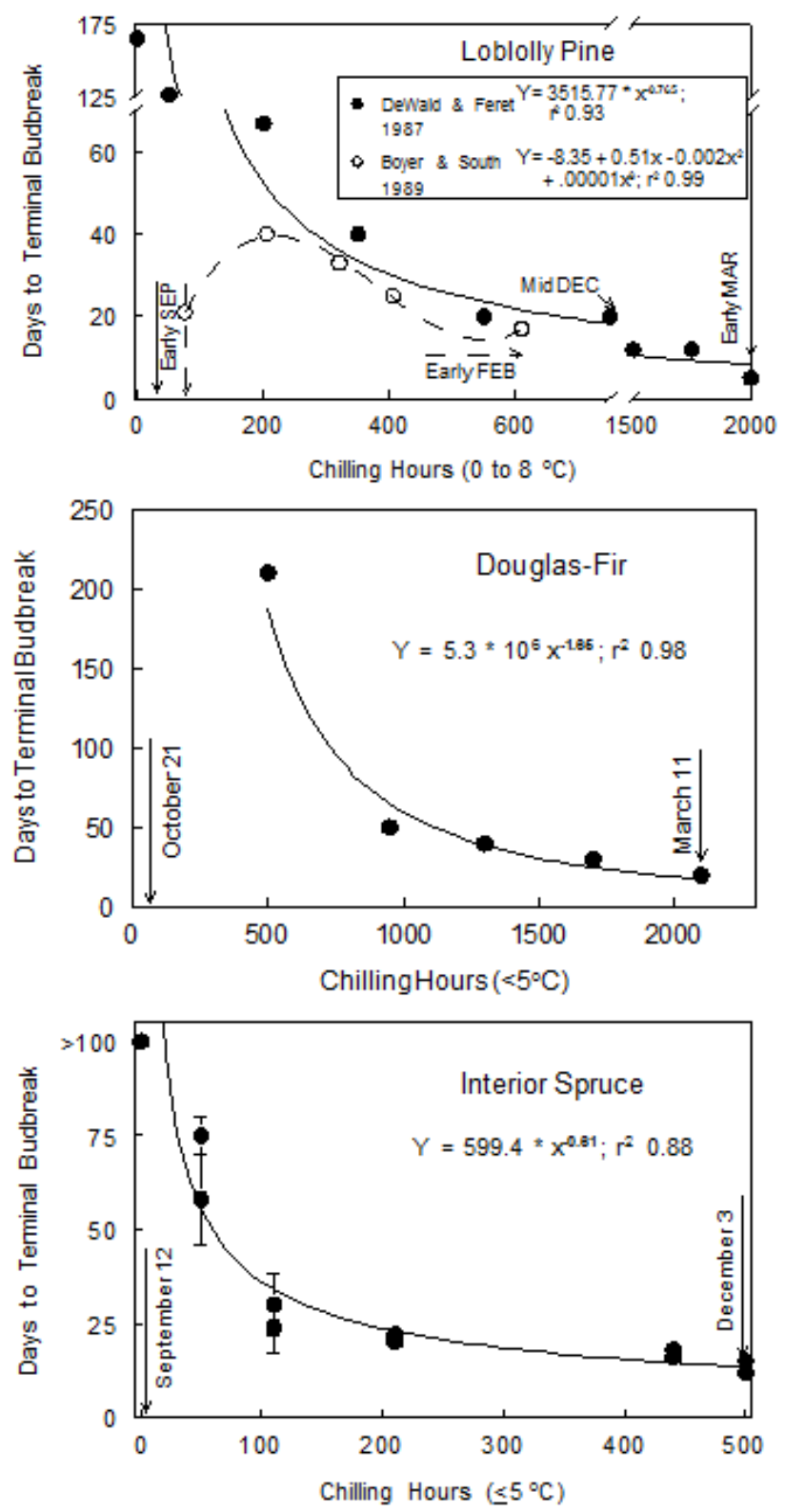

Fig. (1). Change in the days to terminal budbreak in relation to chilling hours during the late summer, fall and winter for loblolly pine (Pinus taeda L.) [25,27], Douglas-fir (Pseudotsuga menziesii var. menziesii) [78] and interior spruce seedlings (Picea glauca (Moench) Voss x P. engelmannii Parry ex engelm.) [93, 143].

\section{Coastal Douglas-Fir}

During mid to late summer, shoot growth slows and terminal buds are initiated in response to the decrease in day length [62]. Complete bud development can take approximately 10 to 13 weeks and thereafter mitotic activity
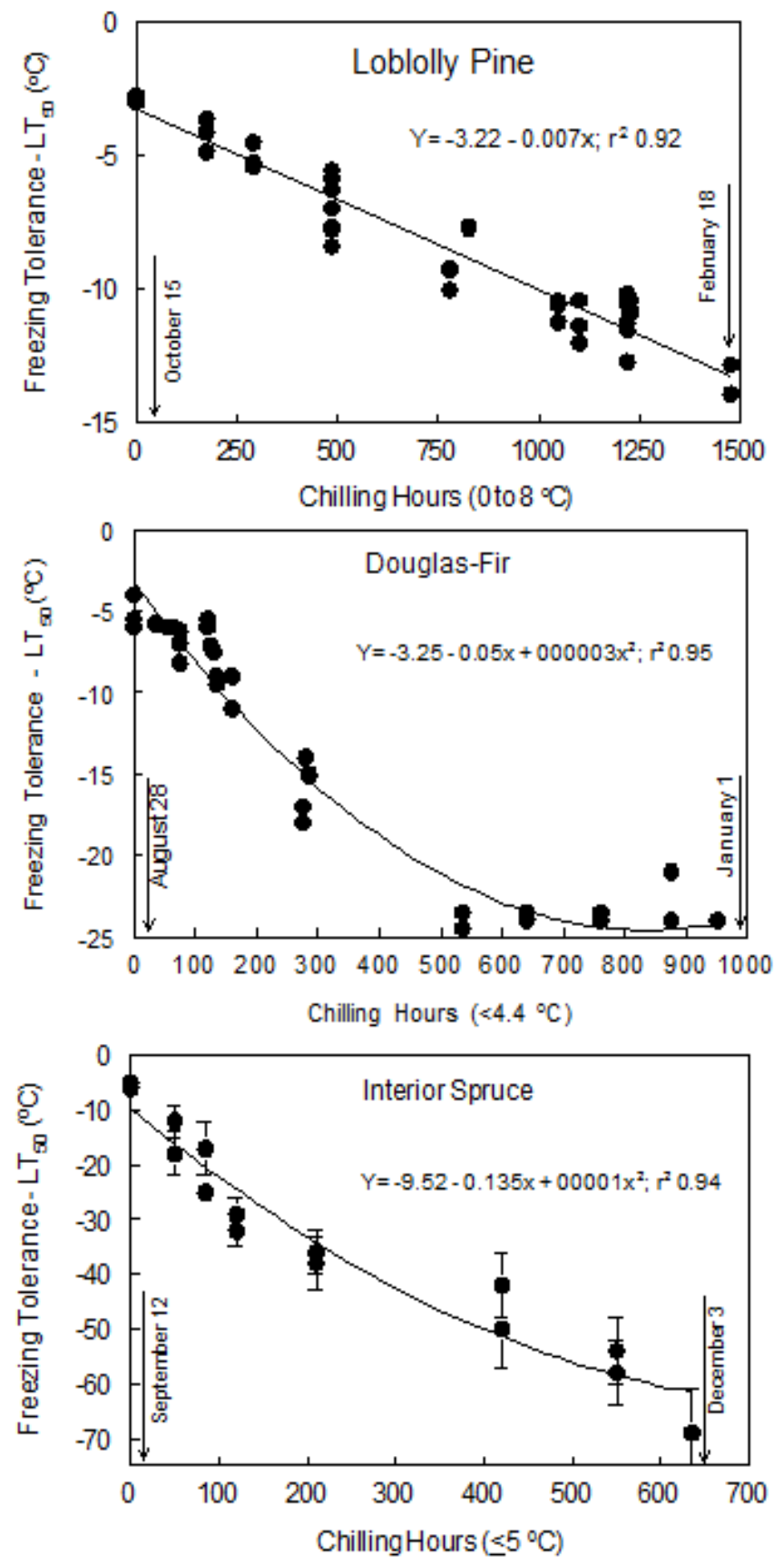

Fig. (2). Freezing tolerance in relation to chilling hours during the late summer, fall and winter for loblolly pine (Pinus taeda L.) (Grossnickle; unpublished data - measured as $50 \%$ electrolyte leakage of needle tissue), Douglas-fir (Pseudotsuga menziesii var. menziesii) [ 30 - measured as temperature for $50 \%$ death of seedling population] and interior spruce seedlings (Picea glauca (Moench) Voss x P. engelmannii Parry ex engelm.) [93, 143 - measured as $50 \%$ electrolyte leakage of needle tissue]. 



Fig. (3). Change in root growth potential in relation to chilling hours during the late summer, fall and winter for loblolly pine (Pinus taeda L.) [27], South unpublished data, Douglas-fir (Pseudotsuga menziesii var. menziesii) [32] and interior spruce seedlings (Picea glauca (Moench) Voss x P. engelmannii Parry ex engelm.) [93,143].

within the bud declines to zero [34, 63, 64]. An endodormant bud does not break even if seedlings are exposed to optimal conditions and long photoperiods [65]. Appropriate hardening practices are required, because prior to hard-bud development, nursery grown seedlings can reflush if optimal cultural conditions are provided [66]. During this phase from active to inactive shoot growth, seedlings start to become tolerant to drought [67] and freezing [30]. The capability to grow roots declines to a low level $[34,40,41]$ though root mitotic activity never completely stops [34, 63]. At this point, terminal buds are in an endodormant state and then fall acclimation typically occurs from September through December/January $[62,68]$.

The transition of coastal Douglas-fir seedlings from an endodormant to an ecodormant state has been related to chilling hour accumulation [65]. This transition is characterized by a decrease in DBB with a low level occurring after exposure to $\sim 2,000$ chilling hours (Fig. 1). There is genetic variation in the way this species moves through this dormancy phase to the point of terminal budbreak [69-71]. This could be why this species needs between 1,700 and 2,000 chilling hours to reach its lowest level of DBB [72, 73].

As natural chilling hours accumulate, there is a rapid increase in freezing tolerance to $\sim 500$ chilling hours $(<4.4$ ${ }^{\circ} \mathrm{C}$ ) with no appreciable increase in freezing tolerance with a further accumulation of chilling hours (Fig. 2). By midJanuary, seedlings reach a maximum level of freezing tolerance ranging from $-18{ }^{\circ} \mathrm{C}[74]$ to $-31{ }^{\circ} \mathrm{C}$ [75]. Coastal Douglas-fir shows genetic variation during fall acclimation with differences in freezing tolerance development related to environmental conditions of the source location [76]. Drought tolerance also increases to a maximum level during this fall acclimation phase [67]. This shift in phenological development towards ecodormancy can produce seedlings with the highest level of stress resistance [73].

The most common root growth pattern observed is an increase in RGP as chilling hours accumulate during the fall [40-41, 63; Fig. (3) - Type \#1]. This was the most common RGP pattern when seedlings were assessed across three years and numerous genotypes [33]. For some genotypes, RGP reaches the highest level after an accumulation of $\sim 800$ chilling hours (Fig. 3) and a similar pattern was observed by others $[77,78]$. This pattern of RGP coincides with shifts in bud dormancy [39]. A less common pattern has adequate RGP in November [32] or December [79] with no significant increase in RGP with additional chilling (Fig. (3) - Type \#2). Also, RGP can have two fall/winter seasonal peaks separated by a significant depression (Fig. (3) - Type \#3). Thus, there is no predictable RGP pattern for Douglas-fir during the fall into winter acclimation phase.

\section{Interior Spruce}

During mid-summer, shoot growth slows and terminal buds are initiated in response to a decrease in daylength [80, 81]. A shift from growing to hardening cultural practices for nursery grown seedlings is required to avoid extended shoot development into late summer, thereby ensuring complete bud development and avoiding damaging fall freezing temperatures [82]. After bud induction, needle initiation follows, with a rapid phase of development for a period of up to six weeks followed by another four week period of slower development [83, 84]. During the last phase of needle initiation, mitotic activity declines to near zero over a period of ten to 12 weeks after bud induction [80,81].

Endodormancy occurs when there is no mitotic activity in the embryonic shoot [65]. During this phase, resistance to drought and freezing begins to increase [85] and RGP 
declines [86, 87]. Endodormancy generally occurs in late summer to early fall [17].

As natural chilling hours accumulate, DBB decreases to a low level (Fig. 1). Nienstaedt [88] found that for several spruce species, the initial 336 chilling hours $\left(<5{ }^{\circ} \mathrm{C}\right)$ were more effective in lowering DBB than subsequent chilling. Amount of chilling required to fully overcome the endodormant state for young spruce seedlings is between $750 \mathrm{~h}$ [89] and 3,350 $\mathrm{h}$ [28]. The varying response is due to genetic variation [17] and possibly due to different chilling hour temperature ranges.

There is a rapid increase in freezing tolerance starting in early September, reaching a maximum level by December. Nienstaedt [88] speculated that chilling is an adaptive trait for spruce to protect against early fall frosts. Freezing tolerance increases rapidly during the fall as average air temperatures decline and chilling hours accumulate $[85,90$, 93]; Fig. (2). Numerous studies have found genetic variation in freezing tolerance development during the fall [17]. During the fall acclimation phase, drought tolerance also increases $[89,93,94]$. Thus, stress resistance develops in interior spruce as it undergoes fall acclimation.

Accumulation of chilling has been related to increases in RGP of interior spruce seedlings (Fig. 3). This root growth pattern has been observed as buds move from an endodormant to an ecodormant state [86, 87]. This root growth pattern coincides with spruce seedlings being in an ecodormant state by December [17]. However, a high RGP has been reported in October [28] and across September through early November [31] indicating that timing of fall shifts in RGP does not always correlate to the accumulation of chilling.

\section{IMPACTS OF NURSERY PRACTICES}

\section{Cultural Practices}

Nursery practitioners have reduced irrigation, fertilization, day length and temperature in order to stop shoot growth and harden container-grown seedlings [95-97]. Bareroot seedlings can be conditioned by withholding irrigation in years with a dry fall, reducing fertilization and by shoot and root manipulation [98-101]. Thus, there are a series of cultural practices prescribed to stop or reduce shoot growth and harden seedlings during the fall acclimation phase and prepare them for the lift/store regime.

Application of a series of water stress events may be used as a nursery cultural practice to induce shoot growth cessation in rapidly growing conifer seedlings. When precipitation in the fall is limited, the practice of withholding irrigation in bareroot nurseries can slow height growth of loblolly pine [102] and initiate budset and earlier induction of dormancy in Douglas-fir [98]. Periodic moisture stress is capable of inducing bud formation in container-grown loblolly pine (Grossnickle unpublished data), Douglas-fir $[66,103]$ and spruce seedlings $[104,105]$. Exposing loblolly pine seedlings to mid-day water potentials of -1.25 to -1.50 $\mathrm{MPa}$ for at least three weeks develops drought resistance (Grossnickle unpublished data). Cleary and others [103] emphasize that moderate water stress (i.e. predawn water potential between -0.5 to $-1.0 \mathrm{MPa}$ ) is desired for effective hardening of Douglas-fir and other Pacific Northwest conifers and that too little or too great a level of water stress has minimal or deleterious effects, respectively, on the hardening process. However, container-grown Douglas-fir seedlings did not move into an endodormant state when exposed to water stress in combination with reduced fertility in early fall [106]. For spruce species, a series of moderate water stress events at the end of the growing season triggers budset and the development of endodormancy, freezing tolerance, and drought tolerance during the fall acclimation phase [17].

Fertilization application during fall acclimation is defined as a two stage process. First, fertilization adjustments (e.g. lower nitrogen application rate), along with periodic moderate water stress, are used in the late summer and early fall to promote either budset or the cessation of shoot growth $[2,66,104,105,107-109]$. The combination of moisture stress, low nitrogen, high potassium and phosphorus and shortened photoperiod have long been considered an appropriate regime for developing hardened container-grown seedlings $[4,95]$. Decreasing the nitrogen concentration to stop shoot growth and start the fall acclimation process is considered a beneficial fall fertilization technique [97]. Second, fertilization adjustment after budset has been used in an attempt to initiate further seedling hardening prior to the lift/store operation. After budset, nitrogen fertilization can have a different effect on the development of freezing tolerance. This practice of fall nutrient loading can contribute to enhanced seedling stress resistance [110]. For example, in spruce species increased nitrogen application in seedlings that have already set bud increases freezing tolerance [111115], while low nitrogen application limits the development of freezing tolerance [42]. Douglas-fir seedlings with budset and low nitrogen levels were less cold hardy than seedlings with higher nitrogen levels [116]. During hardening, Dumroese [117] recommends avoiding nitrogen fertilization regimes that create a deficit or luxury consumption concentration, keeping nitrogen in an optimum range $(1.5 \%$ to $2.5 \%$ ) and applying hardening with other cultural practices. Some nursery managers apply fertilizer solutions high in potassium in hopes of promoting stem lignification [97] and freezing tolerance [118]. In reviewing early literature on potassium use as a cultural practice in cold hardening, Timmis [116] concluded that the balance between potassium and nitrogen determines the level of cold hardiness. In studies with spruce species, phosphorus application promotes freezing tolerance [119], while in other instances there was little effect $[112,113,118]$. The role of nitrogen, potassium and phosphorous in developing freezing tolerance appears to vary with species, rate and timing of application in the nursery [11,17, 120-122].

Short-day treatment is an effective means to initiate budset $[123,124]$ and is used to affect bud dormancy for container-grown Douglas-fir and spruce species [82, 105, 106, 124-128]. Short-day treatment is not recommended for container-grown loblolly pine seedlings [108] because normal daylength has a similar effect in stopping height growth during late summer and fall [129]. 
Shoot and root manipulation is a cultural practice used to harden seedlings in the fall. For example, proper top-pruning of loblolly pine seedlings (months prior to lifting) controls height growth, can increase freezing tolerance [130] and increases the probability of higher field survival after outplanting [101]. In contrast, top-pruning of Douglas-fir effectively controls shoot height [98], but it can delay bud development and result in the reflush of lateral buds [131] which might result in fall frost damage. Root wrenching is another practice used to create stress and thus harden bareroot seedlings during latter stages of seedling development. Wrenching has been used to initiate budset in Douglas-fir [98], to induce moderate stress and harden boreal conifers (e.g. spruce species) [132], and to increase survival and slow shoot development in loblolly pine $[122,133]$.

Interestingly, the practice of "cold conditioning" has been proposed and involves placing fall-lifted seedlings in a cooler (perhaps at $+1{ }^{\circ} \mathrm{C}$ for two or four weeks) or freezer (perhaps at $-1{ }^{\circ} \mathrm{C}$ for two weeks or longer) to increase seedling survival [134] or growth after outplanting [135]. Even though this practice $\left(4\right.$ weeks at $+1{ }^{\circ} \mathrm{C}$ ) may have increased the hardening process of bareroot pine and spruce for one lifting date in October [134], it was not operationally useful when seedlings were lifted earlier or later in the season $[32,134]$. Attempts to apply dark cooler storage hardening to loblolly pine found no development of freezing tolerance, though minimal light in storage caused a comparable rate of freezing tolerance development with chilling hour accumulation as found in outdoor acclimated seedlings (Fig. 2) (Grossnickle unpublished data). To date, a "freezer conditioning" treatment proposed by Ritchie [135] has not been tested across a range of species or stock types and has not been demonstrated to increase seedling survival. Therefore, cold conditioning is not to be considered a standard practice for lift/store regimes.

\section{LIFT TO STORE DECISION}

Successful long-term cooler $\left(+2\right.$ to $\left.+1{ }^{\circ} \mathrm{C}\right)$ or freezer $(0$ to $\left.-4{ }^{\circ} \mathrm{C}\right)$ storage of temperate zone tree species requires that seedlings are able to tolerate extended periods in dark storage. This necessitates a level of hardiness high enough to tolerate this level of stress [11,41]. Lifting for long-term storage of these species ( $>2$ months in coolers or freezers) should only take place when seedling attributes reflect a specific level of bud dormancy $[12,21,31]$. The underlying belief is that the phenological development of terminal buds parallels freezing tolerance and other physiological events that occur as seedlings reach a state of ecodormancy. Regeneration programs for loblolly pine differ from those of coastal Douglas-fir and interior spruce when it comes to deciding what to measure when lifting seedlings for storage.

\section{Loblolly Pine}

A specific set of measurable seedling attributes has not yet been identified to make the lift/store decision for loblolly pine. One issue complicating the identification of a measurable plant attribute is that complete bud development and bud endodormancy are not required in loblolly pine seedlings at time of lifting $[49,53,54]$; Table 1 . The lifting decision of container-grown southern pines is often determined by the ability of the plug to maintain integrity (after extraction from the container) with the storage decision typically based on calendar date [136]. This is because seedlings can sometimes be successfully stored for a month or more without any accumulation of chilling [137]; Table 1; Fig. (4). The planting season of bareroot loblolly pine typically runs from late November through early March $[21,138]$ with lifting for cooler-storage dictated by calendar date and regeneration planting schedules. However, some still believe that chilling hours should be used for both stock types [12, 21], all seed sources and all nursery locations [99]. In a given year, a fixed amount of chilling hours might correlate to storability of bareroot loblolly pine [49] but the correlation remains similar to the number of days after November $1^{\text {st }}$. Thus, there are a number of options in timing of the lift/store activity for loblolly pine.

\section{Coastal Douglas-Fir}

Pacific Northwest nurseries characteristically lift Douglas-fir based on the accumulation of chilling hours $[135,139]$. In theory, this approach of quantifying seedling exposure to fall temperatures standardizes the lifting decision against year-to-year variations in seasonal conditions [12]. In British Columbia, the combination of chilling hour accumulation (D. Swain personal communication) and freezing tolerance (a predetermined temperature threshold of $-12{ }^{\circ} \mathrm{C}$; S. L' Hirondelle, personal communication) measurements is used to make lifting decisions. Freezing tolerance is operationally tested in conifer seedlings (e.g. Douglas-fir and interior spruce) by whole plant freezing, electrolyte leakage of plant tissues or needle chlorophyll fluorescence [140]. Therefore, it is recommended that seedlings be exposed to chilling prior to extended cooler [34] or freezer storage [139]. In contrast, seedlings lifted in early November, with partial chilling, were successfully stored for seven months [141]. This shows that extended storage can be successful, in certain cases, for endodormant seedlings without the recommended extended exposure to fall chilling.

\section{Interior Spruce}

Some nurseries in Canada use chilling hours as a general guideline for lifting seedlings [142]. For example, containergrown interior spruce [143] and bareroot white spruce (Picea glauca (Moench) Voss) seedlings [35] are considered ready for lifting after 500 and 200 chilling hours $\left(<5{ }^{\circ} \mathrm{C}\right)$, respectively. The physiological readiness for freezer storage is defined by tests for freezing tolerance [31, 142, 144]. In British Columbia, spruce seedlings that pass a predetermined temperature threshold (i.e. $-18^{\circ} \mathrm{C}$ ) during the freezing tolerance test are ready for lifting [144, 145]. For example, using this predetermined temperature threshold, interior spruce seedlings reach a low level of freeze injury (i.e. $<15 \%$ injury at $-18{ }^{\circ} \mathrm{C}$ ) after exposure to 200 to 400 chilling hours $\left(<5{ }^{\circ} \mathrm{C}\right)$ [93]. This indicates that interior seedlings are sufficiently hardened to withstand six or more months of frozen storage before planting in mid to late spring [143]. Freezing tolerance testing is also applied in Ontario, where container-grown spruce seedlings are required to be freeze tolerant (i.e. $<10 \%$ shoot injury after freezing to $-40{ }^{\circ} \mathrm{C}$ ) before they are placed in storage [146]. 


\section{STORAGE TYPE USAGE}

Industry recommended standards for cooler storage temperature are +1 to $+2{ }^{\circ} \mathrm{C}$ for storage length of two months or less, while frozen storage temperature guidelines are -2 to $-4{ }^{\circ} \mathrm{C}$ for a storage length of two to eight months [12]. Correct storage practice depends on timing of nursery lift, target planting date and species physiological capabilities. The following discussion examines physiological reasons for cooler or frozen storage.

\section{Loblolly Pine}

Short-term cooler storage is used for loblolly pine as seedlings that are lifted in mid-December and January are typically transplanted before March. The short lift/plant timeframe means that either cooler storage (used currently) or short-term shed storage (used in the past), is acceptable during winter months. December lifted seedlings may be cooler stored up to 11 weeks [25], though most nursery managers do not like to store seedlings more than a month. This is typically enough storage time to meet seedling demands by planting contractors during the winter. There is very limited information on the use of frozen storage as an option for long-term holding of southern yellow pine species. Earlier work reported that frozen storage resulted in death of all fall/winter lifted seedlings [147, 148], while another study found fall acclimated stock was successfully stored at $0{ }^{\circ} \mathrm{C}$ [58]. When kept under a tightly controlled temperature regime, fall acclimated seedlings were successfully freezer stored, though operational testing of similarly treated stock resulted in losses after two weeks of storage (Table 2). Commercial freezer storage facilities with temperatures set at -2 to $-4{ }^{\circ} \mathrm{C}$ resulted in some compartment areas as low as $-6{ }^{\circ} \mathrm{C}$ when the compressor was on cooling mode (Grossnickle unpublished data). Acclimated loblolly pine root systems may only reach a maximum freezing tolerance (i.e. $\mathrm{EL}_{50}$ ) of $\sim-4.5{ }^{\circ} \mathrm{C}$ (Grossnickle unpublished data). Thus, death of seedlings is likely when temperatures of roots in the freezer storage facility drop below the maximum level of freezing tolerance.

\section{Coastal Douglas-Fir}

Coastal Douglas-fir seedlings lifted at the proper level of fall/winter acclimation are typically stored for up to two months in cooler storage [149]. This length of storage is required for late winter field planting programs that are completed by mid-March $[12,150]$. Seedlings can be freezer stored for two to six months when extended lift/store programs are required for proper timing with outplanting programs $[12,135,139,149,151-153]$. Caution needs to be applied since root systems are sometimes only freeze tolerant to a -4 to $-5{ }^{\circ} \mathrm{C}$ temperature range $[154,155]$. Hardened

Table 1. Effect of stock type on survival and root-growth potential (RGP 31 day) of loblolly pine (Pinus taeda L.) $_{\text {. }}$ seedlings were lifted on 20 September, 2007 and stored in a cooler $\left(2{ }^{\circ} \mathrm{C}\right)$ until 9 November or 12 December. $\mathrm{N}=60$ seedlings for survival; 30 seedlings for RGP (South unpublished data).

\begin{tabular}{|l|c|c|c|}
\hline \multicolumn{1}{|c|}{ Stock Type } & Storage Length (weeks) & Survival (\%) & RGP (new root \#) \\
\hline \hline Container & 7 & 100 & 16.4 \\
\hline Bareroot & 7 & 47 & 2.6 \\
\hline Container & 12 & 98 & 10.5 \\
\hline Bareroot & 12 & 0 & 1.3 \\
\hline
\end{tabular}

Table 2. Performance of fall acclimated (seedlings were lifted and stored after 750 chilling hours) loblolly pine (Pinus taeda $\mathbf{L}$.) after an extended time in frozen storage (i.e. controlled freezer at -1 to $-2{ }^{\circ} \mathrm{C}$ or an operational freezer set at -2 to $-4{ }^{\circ} \mathrm{C}$ with temperatures oscillating around this range by $2{ }^{\circ} \mathrm{C}$. Performance of seedlings was determined by survival, the average (AVG) time to express shoot flush and root-growth potential (RGP 21 day $)$; $=30$ plants. (Grossnickle unpublished data).

\begin{tabular}{|c|c|c|c|c|c|c|}
\hline $\begin{array}{l}\text { Storage Length } \\
\text { (Weeks) }\end{array}$ & \multicolumn{6}{|c|}{ Frozen Storage Treatments } \\
\hline 1 & 10.7 & 18.7 & 100 & 11.2 & 19.5 & 100 \\
\hline 6 & 11.2 & 23.3 & 100 & 0 & 0 & 0 \\
\hline 12 & 10.5 & 20.9 & 100 & NA & NA & NA \\
\hline 18 & 6.5 & 26.9 & 97 & NA & NA & NA \\
\hline
\end{tabular}


seedlings may not survive freezer storage at $-5{ }^{\circ} \mathrm{C}$ [29]. In other instances, root systems were freezing tolerant to -8 to $-10{ }^{\circ} \mathrm{C}[144,156]$. This range of root system freezing tolerance could be related to genetic variation. Thus freezer units that oscillate below a temperature of $-5{ }^{\circ} \mathrm{C}$ may cause seedling damage, within certain seedlots, and result in poor field performance.

\section{Interior Spruce}

Fall lifted interior spruce seedlings are typically only freezer stored because there needs to be four to six months between lifting and spring planting $[9,17,142]$. Short term cooler storage is used in summer planting programs for hardened interior spruce seedlings [157]. Fall lifted seedlings are usually placed in frozen storage at -2 to $-4{ }^{\circ} \mathrm{C}$ and as low as $-6{ }^{\circ} \mathrm{C}$ [158] while still maintaining seedlings of high quality. Spruce seedlings root systems are tolerant to temperatures as low as -20 to $-25{ }^{\circ} \mathrm{C}$ [17]. This means that interior spruce seedlings can tolerate freezer temperatures and still exhibit root and shoot growth needed for establishment.

\section{STORAGE LENGTH AND SEEDLING QUALITY}

Storage practices influence seedling quality. Storage conditions should allow seedlings to maintain the physiological integrity required for high RGP needed to overcome planting stress [19], because high RGP improves chances for successful seedling survival [7]. A dark, cold/frozen environment for extended periods of time is an unnatural environment for seedlings, as they are unable to maintain normal biological processes. There are two primary environmental limitations of cold/frozen storage. First is the lack of light as radiant energy required for photosynthesis. Second is seedling exposure to either a constant cold and high humidity environment, or a freezing and low humidity environment.
Seedlings lifted and stored correctly are rarely damaged by cool temperature storage $[10,11]$, though plant deterioration can occur as storage time lengthens [10]. A side effect of cooler storage practices is that extended exposure to cold and high humidity creates conditions for storage molds $[139,151,159]$. Freezing temperature and low humidity of freezer storage prevent storage molds [160], but create freezing conditions where desiccation develops slowly due to gradual water loss via cuticular and peridermal transpiration [161]. Following examples show how storage practices for loblolly pine, Douglas-fir and interior spruce can affect seedling quality.

\section{Loblolly Pine}

Assuming the planting season begins in December and ends on 1st March [162], proper hardening practices should allow sufficient storage length for most nurseries to have quality seedlings available for the winter planting window. When lifted in mid-December and January, bareroot seedlings are generally tolerant of nine weeks or more of cooler storage [25, 27, 163-165]. Even so, some nursery managers only keep a two-week supply of seedlings in storage during winter months.

Short-term cooler storage can maintain seedling quality without previous exposure to chilling. Historically, bareroot seedlings need to be hardened off and "dormant" before they could survive cooler storage $[163,166]$. However, the combination of low irrigation and low $\mathrm{N}$ hardened containergrown stock allows storage of non-chilled seedlings for four to six weeks (Fig. 4). This agrees with work reporting that hardened container-grown seedlings were cold-stored for four weeks without any chilling requirement [167]; Table 1. Adequate lignification might also explain why bareroot pine seedlings sometimes store well when lifted in November (with exposure to fall hardening cultural practices) but with minimal exposure to chilling $[27,122,137]$.

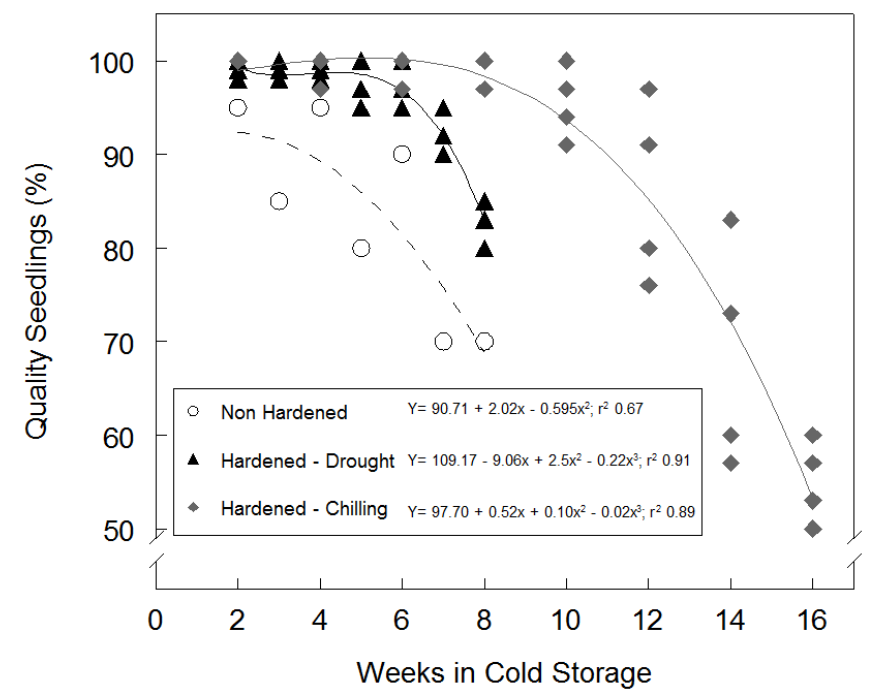

Fig. (4). The effects of cultural practices on the quality of container-grown loblolly pine (Pinus taeda L.) (i.e. stock that are alive and have both shoot flush and root growth in a 21 day test; $\mathrm{N}=30)$ after being removed from cooler storage $\left(2-4{ }^{\circ} \mathrm{C}\right)$. Non hardened stock were actively growing, while hardened stock had stopped growing after exposure to a finishing fertilizer and either 4 weeks of drought or 750 chilling hours $\left(0\right.$ to $\left.8^{\circ} \mathrm{C}\right)$ (Grossnickle - unpublished data). 
Natural chilling prior to storage can increase seedling quality. The combination of 750 chilling hours and low nitrogen fertility allows seedlings to be stored for 10 to 12 weeks (Fig. 4). Based on RGP data, DeWald and Feret [27] stated that 500 chilling hours were necessary for successful cooler storage for up to 12 weeks. Seedlings lifted in midDecember with an accumulation of perhaps 400 chilling hours [165] or in early December [164] were successfully cooler stored for two months or more.

Chilling is not an absolute requirement for short-term cooler storage. For example, a study on container-grown seedlings lifted in September (i.e. no chilling) had good RGP and high survival after seven and 12 weeks of cooler storage, while similarly stored bareroot seedlings had low RGP and low survival (Table 1). This finding agrees with that of Mohammed and others [168] who said that "During overwinter storage, bareroot seedlings may be more vulnerable to physiological deterioration than container seedlings." It is not known why November or October-lifted, bareroot loblolly pine seedlings can sometimes be stored for a month [27, 137] while in other cases RGP drops quickly after seedlings are placed into cooler storage.

There are a number of possible factors causing variability in quality of stored seedlings. First is the level of freezing tolerance at lift. When fall-lifted seedlings were placed in coolers, freezing tolerance development ceased (Grossnickle unpublished data) while, seedlings placed outdoors continued to acclimate to cold temperatures during fall and winter [55]. When seedlings are lifted and stored in November (with minimal freezing tolerance) and then outplanted in December, just prior to a $-7^{\circ} \mathrm{C}$ freeze, they likely have low survival due to their lack of freezing tolerance. In contrast, in years with a mild winter, seedlings lifted and stored in November and planted in December had adequate survival [122].
Second is the realization that succulent seedlings typically do not store well. Plants develop stress resistance when they have "hardened off" and are in an inactive growth phase [44]. However, loblolly pine seedlings are not inactive and can grow in diameter and biomass throughout the winter [52,169]. Even so, through various cultural practices, seedlings can develop a level of hardiness that tolerates cooler storage for extended periods (Fig. 4). Thus, there are a number of cultural pathways available to harden loblolly pine for cooler storage.

Third, disease plays a major role in seedling storability. Some Pythium species grow well in cool, moist environments (e.g. cooler storage). Treating roots with certain fungicides can improve storability of bareroot southern pine seedlings [170-172]. RGP was reduced in the fall when seedlings were infected with certain Pythium species [167]. Bareroot nursery lifting operations cause wound to roots and this may attract zoospores of various Pythium species [173]. Once seedlings are placed in storage, a cool and moist environment is conducive for zoospore activity, leading to root disease and reduced survival after transplantation [167].

\section{Coastal Douglas-Fir}

Recommended practice of cooler storage for Douglas-fir is only for eight to 10 weeks before planting in a late winter or early spring [150]. Seedlings going through fall acclimation were successfully freezer stored for two months [135] and successfully cooler stored for five [34] to seven months [141]. However, two to three months of cooler storage may cause a drop in days to budbreak [29]; Fig. (5). Cooler storage can cause a changeable RGP response; reduced RGP [79]; Fig. (5), consistent RGP [174], or variable RGP (i.e. lower values in fall and spring and higher values in winter when compared to non-stored seedlings)

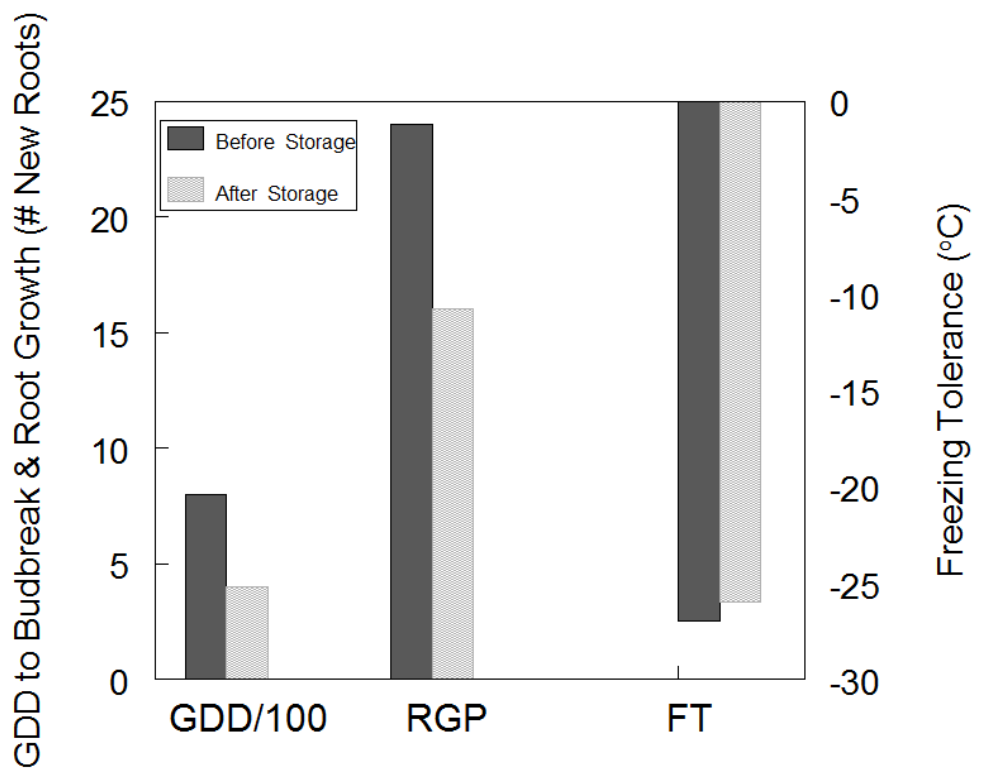

Fig. (5). Shifts in the growing degree days to budbreak (GDD), root growth potential (RGP) and freezing tolerance (FT - 50\% needle damage) of fully fall acclimated Douglas-fir fir (Pseudotsuga menziesii var. menziesii) seedlings after eight weeks of cooler $\left(2{ }^{\circ} \mathrm{C}\right)$ storage [63]. 
[77]. Freezing tolerance was maintained throughout cooler storage [174, 175]; Fig. (5). Maintenance of freezing tolerance occurred during two months cooler storage despite a loss of $28 \%$ [176] to $45 \%$ [63] of food reserves (i.e. total nonstructural carbohydrates). The theory that chilling during storage increases the physiological quality of Douglas-fir [135] has not yet been proven. Cannell and others [63] found no linkage between DBB and freezing tolerance. Chilling in a dark cooler decreased DBB but did not increase freezing tolerance (Fig. 5). Cooler storage beyond two months can cause molds and root diseases $[139,151]$ that can, in certain instances, reduce seedling quality [177]. Extended storage (i.e. 12 to 19 weeks) of bareroot stock showed increased root damage [178] resulting in lower field survival [79]. Managers holding Douglas-fir seedlings in coolers or freezers beyond two months should apply monitoring and/or treatment programs to detect potential problems.

\section{Interior Spruce}

Seedlings are usually placed in frozen storage and held for periods of four to six months [17, 142]. Placing spruce seedlings in frozen storage in a state of maximum stress resistance maintained their physiological quality throughout storage [31, 144, 158]. However, even in frozen storage, seedlings are still physiologically active (i.e. at a low level) and this is reflected in changes in DBB, RGP and freezing tolerance. A decline in DBB occurred during extended freezer storage (Fig. 6) [28]. The ability of freezer-stored spruce seedlings to grow new roots was maintained [31,179] or declined [28, 180]; Fig. (6), though in the reported example seedlings still had $\sim 100$ new root growing tips after five months of storage. Declining root growth may indicate that extended storage shifts the natural sequence of next season growth events from root to shoot growth [9]. There is also speculation that a decline in RGP may be due to a depletion of carbohydrate reserves during storage [181].
Interestingly, in Norway spruce seedlings (Picea abies (L. Karst.) carbohydrate levels declined during the initial five months of freezer storage and thereafter kept relatively stable during three additional months of storage [182]. Carbohydrate depletion in frozen-stored spruce seedlings corresponded with a declining RGP after extended storage [183] and a slower resumption in root growth after planting [184]. However, levels increased quite rapidly after planting frozen-stored spruce seedlings [185] indicating a rapid recovery in the ability to provide photosynthates for root growth. While in frozen storage, spruce seedlings can lose part of the freezing tolerance developed during the fall prior to lifting (Fig. 6). Other spruce species have also shown a loss of freezing tolerance during frozen storage [28, 63, 186]. A loss of carbohydrate reserves occurs in frozen conifer seedlings $[187,188]$ and spruce seedlings have low levels of respiration during frozen storage [189]. Ritchie [73] speculated that this loss in freezing tolerance was due to a reduction in carbohydrate reserves and a lack of photosynthesis.

Spruce seedlings had a high degree of drought tolerance and avoidance capability during the winter period, enabling them to withstand mild levels of desiccation during frozen storage [17]. However, when severe desiccation occurred during storage it caused a reduction in RGP [190] and increased needle damage [191]. This loss in water content over an extended frozen storage period had no effect [192] or a negative effect [191] on seedling quality.

\section{FIELD PLANTING AND PERFORMANCE}

Hardened seedlings typically tolerate many stresses that may occur after outplanting [4, 193, 194]. However, planting stress-resistant seedlings does not guarantee high survival rate. Rather, the interaction of seedling quality and field environment determines the potential for seedlings to

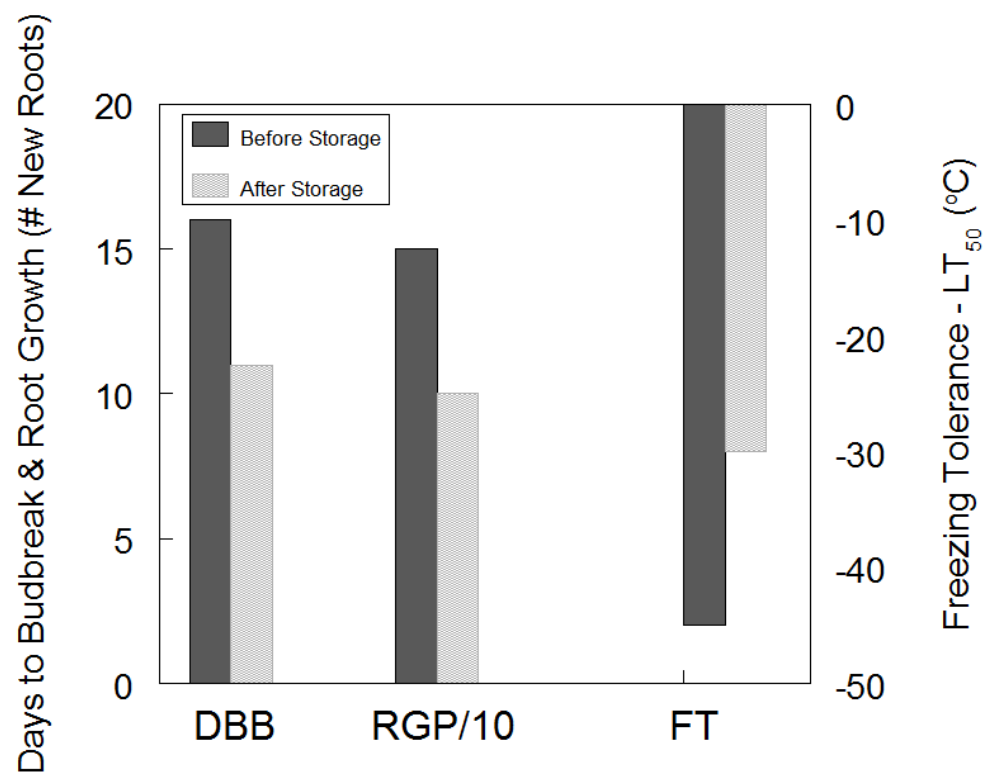

Fig. (6). Shifts in the days to budbreak status (DBB), root growth potential (RGP) and freezing tolerance (FT - measured as $50 \%$ electrolyte leakage of needle tissue) of fully fall acclimated interior spruce seedlings (Picea glauca (Moench) Voss x P. engelmannii Parry ex engelm.) over 23 weeks of frozen $\left(-2^{\circ} \mathrm{C}\right)$ storage $)$ [143]. 
become established [7, 17]. It has long been recognized that lift/transplant date has a direct effect on field survival of bareroot [2] and container-grown [66] seedlings due to environmental conditions in the field and changes in seedling quality. Nursery cultural practices related to fall acclimation and date of lifting as they affect the field performance of loblolly pine, Douglas-fir and interior spruce seedlings are discussed below.

\section{Loblolly Pine}

Depending on the field environment, loblolly pine (bareroot and container-grown) can be successfully lifted and transplanted in all months of the year $[108,195]$. Timing of lifting is often determined more by reforestation site environmental conditions than by the presence of a wellformed terminal bud, level of freezing tolerance, or stage of bud endodormancy. Ideally, container-grown seedlings would be lifted and field planted before December to avoid having to protect outside-grown seedlings from hard freeze events [196, 197]. November to February is the preferred planting window for bareroot stock since this period (in the southern US) has low evapotranspiration and longer periods of adequate soil moisture. Seedlings of both stock types undergo less transplanting stress when temperatures are cool, evaporative demand low and soil moisture adequate [19]. Availability of tree planters and planting site environmental conditions are the two main factors determining when loblolly pine seedlings are shipped from the nursery.

The ability of loblolly pine seedlings to be cooler stored is not only the result of exposure to chilling. Loblolly pine seedlings hardened, but not exposed to chilling in the early fall were stored successfully and had high field survival (Fig. (7); Table 1). In addition, continued exposure to fall temperatures had no beneficial effect on improving seedling storability and subsequent field survival (Fig. 7) [122]. To date, researchers have failed to demonstrate a cause-andeffect relationship between natural chilling and storability of loblolly pine seedlings. In contrast, there is strong evidence on the importance of chilling to increase freezing tolerance (see Fall Acclimation Section). This may be critical for survival (in some years) because early storage prevents seedlings from developing sufficient freezing tolerance to withstand a hard freeze soon after outplanting. Previous discussion (see Storage Length and Seedling Quality) showed how hardening practices allowed for a storage length that was sufficient for most nurseries to have quality seedlings available for the winter planting window. In some cases, fall chilling can improve storability (Fig. 4), though other hardening practices (e.g. top-pruning, fertilization and watering regimes) are also effective in improving chances of seedling survival.

\section{Coastal Douglas-Fir}

Fall acclimation process of coastal Douglas-fir seedlings creates a stock type that by time of fall/winter lifting has high field survivability. In contrast, seedlings lifted in late summer and early fall, prior to fall acclimation, had low survival after cooler storage [77,198, 199]. In some cases, lifting prior to December resulted in lower survival of stored stock [200]. Perks and others [152] found that bareroot seedlings lifted in November had lower survival than nonstored seedlings when cooler or frozen stored, while seedlings lifted in January and February had high survival $(>90 \%)$ compared to non-stored seedlings. Several researchers suggest that chilling was required to consistently have high survival in lifted and cooler stored seedlings [32, $34,79]$. Others found that seedlings with a high DBB at lifting had low survival while seedlings with a low DBB had high survival after removal from cooler storage [198]. The level of pre-storage freezing tolerance was correlated to seedling exposure to a number of chilling hours prior to lifting, and this increased hardiness directly related to their survival after removal from storage and planted [79, 144]; Fig. (8). In some studies, there appeared to be an upper limit to the relationship between chilling hours and stress resistance $[29,79]$. In one case, seedlings exposed to 562 chilling hours $\left(<4.4{ }^{\circ} \mathrm{C}\right)$ developed freezing tolerance but

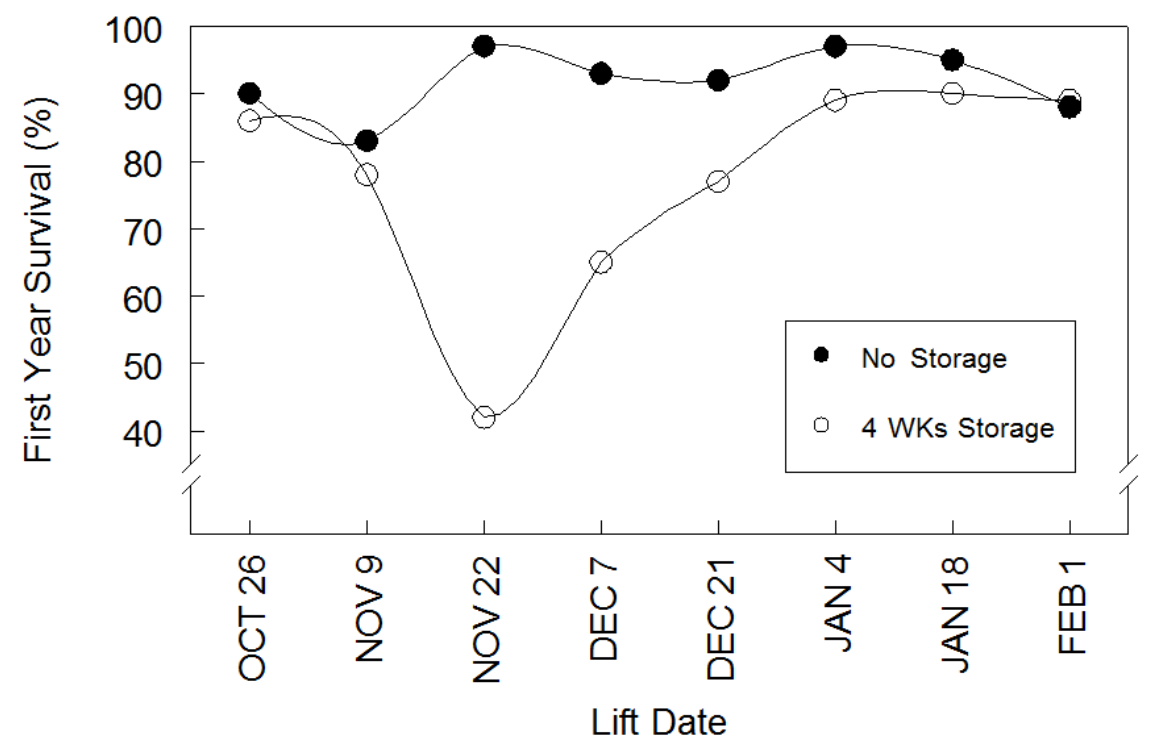

Fig. (7). First-year survival of loblolly pine (Pinus taeda L.) seedlings by lift date and length in cooler storage $\left(3{ }^{\circ} \mathrm{C}\right)[137]$. 
additional chilling had no further improvement in stress resistance (Fig. 8). Interestingly, Douglas-fir (Pseudotsuga menziesii var. glauca) seedlings showed only a minimal response of increased hardiness to chilling hours prior to lifting. In contrast, seedlings lifted in early November exposed to extended cooler storage had high survival when assessed in a greenhouse [29] or under field conditions [141]. In these two examples, seedlings with minimal exposure to chilling developed adequate levels of fall hardening to handle lift/store practices and survive after planting. Fall acclimation of Douglas-fir seedlings, with or without extensive chilling, develops a level of hardiness that enables them to handle lengthy periods of cooler storage and survive outplanting.

\section{Interior Spruce}

Throughout Canada, seedlings are lifted in the fall after they are able to survive a defined freezing temperature [11]. The underlying belief is that the development of freezing tolerance occurs in parallel with other phenological and physiological events as spruce seedlings go through fall acclimation and reach an ecodormant state [17]. When interior spruce seedlings passed a freezing test (i.e. low relative conductivity) they underwent lengthy freezer storage and still had high field survival [31, 144]; Fig. (9). Seedlings lifted after November $1^{\text {st }}$ also had sufficiently hardened during fall acclimation (i.e. comparable to fall conditions reporting high survival in Fig. 9) to have high survival and growth after six months of frozen storage [28]. Fully acclimated interior spruce seedlings can withstand frozen storage and have high field survival after field planting.

Seedlings frozen for an extended timeframe require a time period to resume normal physiological responses after removal from storage. Standard practice for thawing frozenstored seedlings is to remove them from storage and slowly thaw plugs in the dark, or low light at low temperatures (0-3 ${ }^{\circ} \mathrm{C}$ ) for a defined period (e.g. 2 weeks - [201]; 3 to 5 weeks [202]; 6-weeks [203] or rapidly thaw at a higher temperature (5-10 ${ }^{\circ} \mathrm{C}$ ) for five to 10 days [202-203]). Silim and Guy [204] recommended thawing frozen-stored seedlings for the shortest feasible time, as it resulted in seedlings of the highest physiological quality for subsequent field performance. Alternatively, spruce seedlings have been planted with frozen [205] or rapidly thawed container plugs [206] with no deleterious effects on their overall physiological performance. Camm and others [206] found that even though initial root growth of frozen-planted seedlings was less than slow-thawed seedlings, all had comparable root development 15 days after planting. In addition, rapid thawing practices had no subsequent effect on morphological development over the first $[205,206]$ and second growing seasons [207]. In contrast, work reported on Norway spruce found that planting frozen compared to thawed seedlings caused lower initial root growth, thereby resulting in lower survival [208]. Thus, planting frozen seedlings should be done with caution because there are field situations where reduced root development limits seedling access to soil water and increases chances for planting stress [19].

Conifer seedlings stored in freezers required more days of favorable conditions to become physiologically active compared to cooler stored seedlings [209]. The gas exchange capability of frozen stored spruce seedlings took from one [210-212] to four weeks [184, 213] before they were comparable to actively growing seedlings. Frozen stored seedlings also initially had a high resistance to water flow through the plant [210], creating water stress during initial

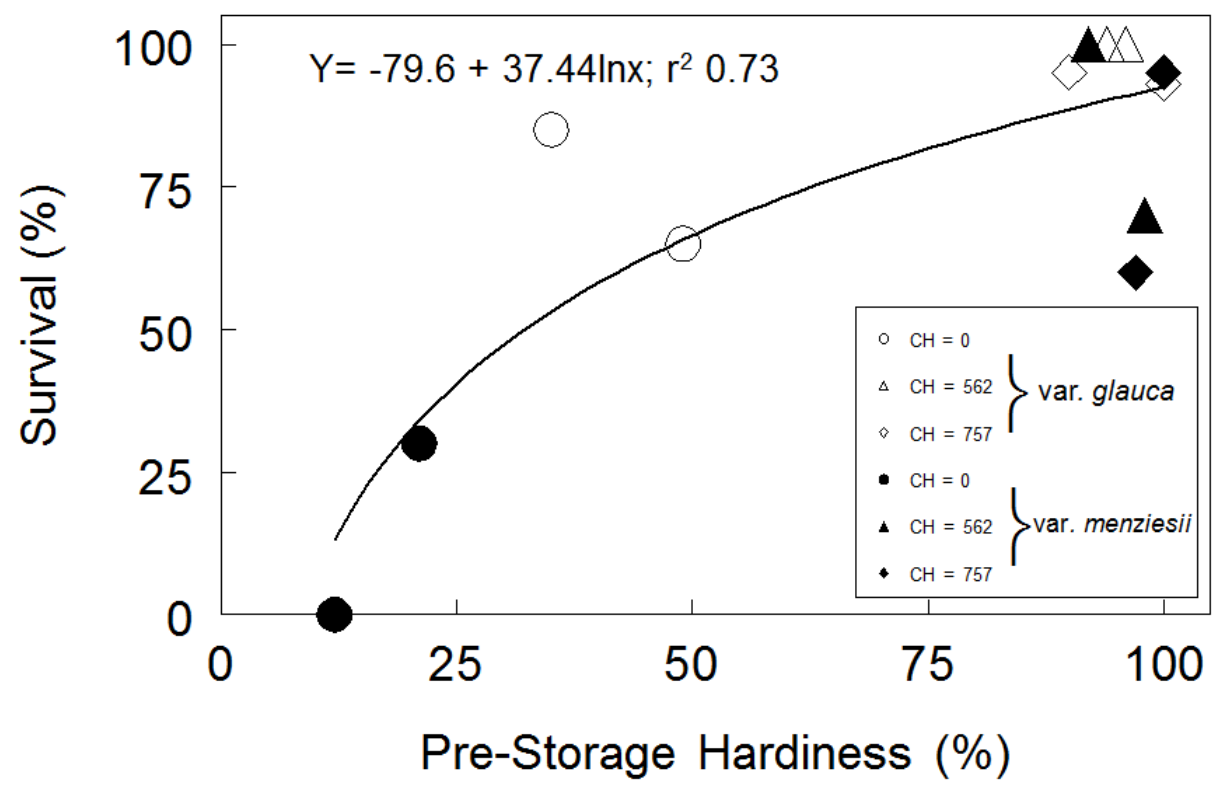

Fig. (8). Relationship between seedling survival and prestorage hardiness (i.e. determined by an exposure to a range of freezing temperatures after a set number of chilling hours $\left[\mathrm{CH}=<4.4{ }^{\circ} \mathrm{C}\right]$ ) of Douglas-fir (Pseudotsuga menziesii var. menziesii and var. glauca) seedlings. All seedlings were stored at $2{ }^{\circ} \mathrm{C}$ for 16 weeks, subjected to a post-storage freezing test, and then survival was recorded after eight weeks in a greenhouse [adapted from 29]. 
days after planting, even when soil water was available [206]. Similar physiological response patterns are reported when planting frozen Douglas-fir (Pseudotsuga menziesii var. glauca) seedlings [214, 215]. Alleviation of planting stress is predicated on seedlings resuming root growth very soon after field planting [19] and as frozen-stored seedlings resume root growth they achieve a non-stressed plant water balance $[206,210]$. Since frozen storage practices result in a slower resumption in normal gas exchange capability and root growth, reforestation programs need to time planting so field site environmental conditions minimize exposure of newly planted seedlings to planting stress [150].

\section{SPECIES COMPARISON}

\section{Fall Acclimation}

There is a broad range of temperatures used to define chilling hours. Loblolly pine chilling hours are typically defined as 0 to $8{ }^{\circ} \mathrm{C}$. Coastal Douglas-fir and interior spruce chilling hours can include below freezing conditions, while maximum temperature values range from 4.4 to $10{ }^{\circ} \mathrm{C}$. Caution is required when drawing general observations regarding fall acclimation patterns in relation to chilling hours. Loblolly pine, Douglas-fir and interior spruce all acclimate in the fall, though they have unique patterns of bud dormancy development, freezing tolerance and RGP.

Douglas-fir and interior spruce show a fairly predictable pattern during fall acclimation; interior spruce reaches an endodormant state in late summer and Douglas-fir in early fall with the development of a hard bud and high DBB at the start of fall that transits into a decline in DBB. In certain instances, loblolly pine follows similar DBB pattern during fall acclimation, though there are reported instances where loblolly pine does not follow this fall acclimation pattern (lack of development of a hard bud, continued mitotic activity, rapid changes in DBB).
All three species show increased freezing tolerance as natural chilling hours accumulate throughout the fall and winter, though Douglas-fir reaches a plateau in freezing tolerance development after $\sim 500$ chilling hours $\left(<5{ }^{\circ} \mathrm{C}\right)$, while loblolly pine and interior spruce may continue to develop freezing tolerance with continued exposure to chilling hours. For loblolly pine, Douglas-fir and interior spruce, maximum level of freezing tolerance development is reported to be $-15{ }^{\circ} \mathrm{C},-31{ }^{\circ} \mathrm{C}$ and $-70{ }^{\circ} \mathrm{C}$, respectively, with maximum level of freezing tolerance related to the genetic make-up of tested sources. However, loblolly pine may never reach this level of freezing tolerance because many nursery locations below latitude $34^{\circ} \mathrm{N}$ do not receive sufficient chilling hours during the winter.

All three species may show an increase in RGP with the accumulation of chilling hours. However, all species can also have high RGP across the entire fall acclimation period, while Douglas-fir is also reported to have a bi-modal fall/winter RGP pattern. This indicates that these species do not have a consistent RGP pattern during fall acclimation.

\section{Lift to Store Decision}

The more predictable fall acclimation pattern of Douglasfir and interior spruce has allowed reforestation programs in the Pacific Northwest and boreal forests to develop seedling quality assessment approaches (e.g. accumulated chilling hour values and defined freezing tolerance levels) for determining the time to lift seedlings for storage. In certain instances, Douglas-fir seedlings have been successfully stored and show high field survival with partial exposure to fall chilling. Thus, extended storage can be successful, in certain cases, for hardened seedlings of this species without extended exposure to fall chilling. Practitioners need to be cautious in using the same measures for determining the time to lift loblolly pine seedlings. To date, the hypothesis that chilling regulates seedling storage for loblolly pine has not

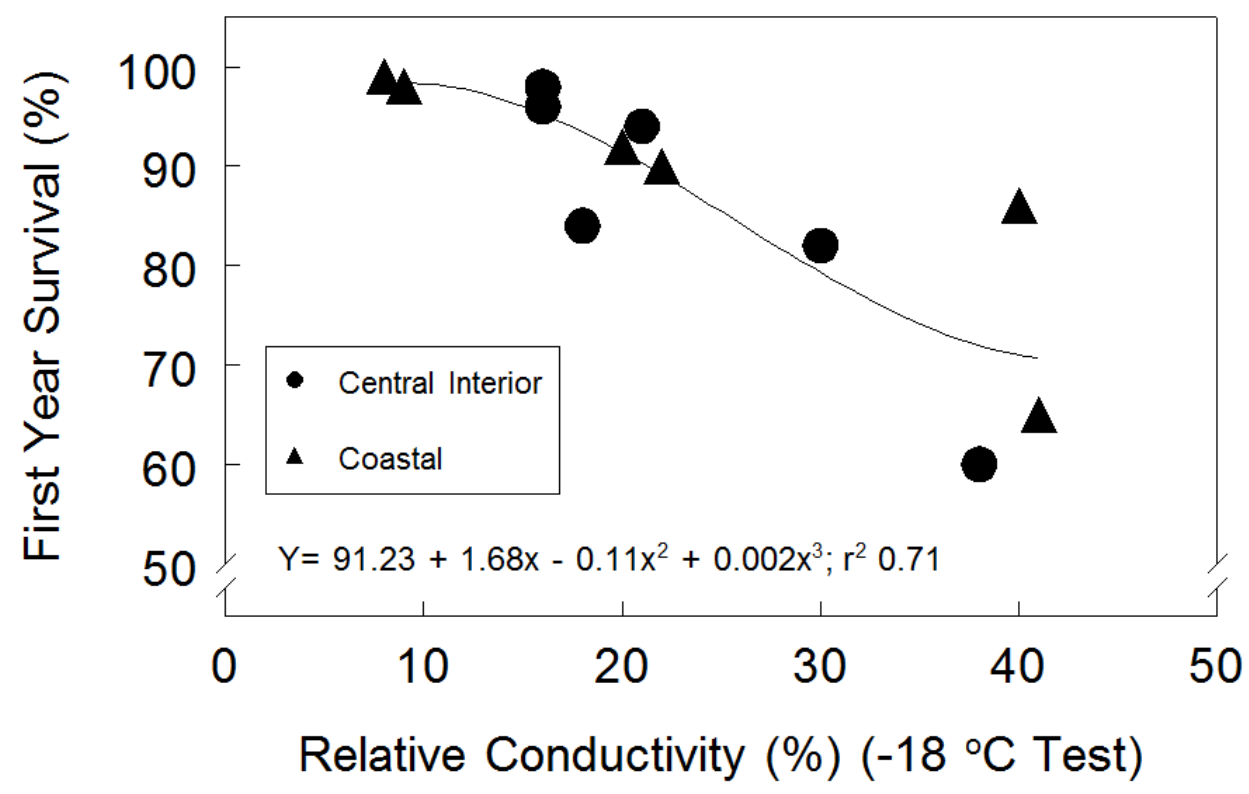

Fig. (9). Survival of field planted interior spruce seedlings (Picea glauca (Moench) Voss x P. engelmannii Parry ex engelm.) versus their prestorage freezing damage assessed by electrolyte leakage tests of needle tissue. Seedlings were taken from a central interior and coastal nursery (i.e. lifted between September 25 and October 30) and stored at $-2{ }^{\circ} \mathrm{C}$ for 23-35 weeks [adapted from 145]. 
been confirmed, so there is no proven measurable plant attribute to make the lifting decision.

\section{Storage Type and Usage}

Loblolly pine, Douglas-fir and interior spruce can be cooler stored to meet lift/store requirements of a few months prior to field planting. However, fall lifted interior spruce seedlings are typically freezer stored due to the extended time between lifting and planting dates. Determination of the capability of a tree species to be freezer stored needs to be dictated by plant parts that are most susceptible to freezing temperatures. Root systems of plants do not develop the same level of freezing tolerance as shoot systems and thus are more susceptible to frost events [161,216]. Root systems of interior spruce seedlings are tolerant to low freezing temperatures that are well below the temperature range used in operational freezer storage programs. In contrast, loblolly pine and coastal Douglas-fir root systems are freeze tolerant to temperatures at or just below freezer storage $\left(0\right.$ to $\left.-4{ }^{\circ} \mathrm{C}\right)$. Thus, these species are susceptible to freeze damage when operational storage unit temperatures drop into a range that can damage root systems. The selection of the proper storage practices is critical because freeze-damaged seedlings showed reduced survival and growth after field planting [217].

\section{Storage Length and Seedling Quality}

Loblolly pine seedlings are lifted, kept in storage for a minimal time, and then outplanted in late fall and winter. They need to be hardened to undergo a lift/store regime of up to two months, retain a high level of seedling quality and have high survival after outplanting. As a result, cultural practices are used to stop or slow shoot growth and develop stress resistance (with or without exposure to chilling) so seedlings can withstand time in cooler storage. Reforestation programs in the South utilize both bareroot and container stock types, with loblolly pine container-grown seedlings able to withstand storage longer than bareroot seedlings. A key factor determining length of cooler storage of loblolly pine may reside in roots rather than the shoot. Further research is required to test this hypothesis. In the Pacific Northwest and across the boreal forests, there is a longer time span between fall lifting programs and planting of conifers than in the South. Thus, Douglas-fir and interior spruce typically have a longer time between fall lifting and planting. Hardening cultural practices along with typical fall exposure to chilling provide practitioners with a means to set up Douglas-fir and interior spruce seedlings for long term storage. Fall acclimated Douglas-fir seedlings that are properly hardened can be successfully cooler stored for two to five months; with longer storage times potentially resulting in storage molds and a reduction in root quality. Fall acclimated interior spruce seedlings can maintain good quality during four to six months of freezer storage. However, seedling quality can change during extended storage (i.e. decline in DBB, freezing tolerance, RGP, carbohydrate reserves, possibly seedling desiccation) so there are potential limits to storage length.

\section{Field Planting and Performance}

Nursery practices during fall acclimation and lift date affect the field performance of all three species. Loblolly pine seedlings need to be hardened to undergo a lift/store regime and have high survival after outplanting. However, when loblolly pine seedlings are transplanted several weeks prior to a freeze, chilling (prior to lifting) is not required for this species to be stored successfully and have high field survival. Douglas-fir and interior spruce seedlings that have achieved an appropriate length of fall acclimation develop a level of hardiness that enables them to handle lengthy periods of storage and survive after field planting. Planting seedlings with a specific level of hardiness is not a requirement for ensuring field survival; rather it increases their chances for survival [7]. Thus, application of specific cultural practices is recommended for each species to provide seedlings the best chance of handling lift/store regimes and have high survival after being outplanted.

\section{CONCLUSION}

Loblolly pine, Douglas-fir and interior spruce all go through fall acclimation and can be successfully stored prior to outplanting. However, each species has a unique fall acclimation pattern. Therefore, it is difficult to declare that all three species are guided by the same framework during fall acclimation. Knowing the unique characteristics for each species allows practitioners to define appropriate fall acclimation cultural programs. This ensures a level of hardiness that enables seedlings to handle lengthy periods of storage and survive after outplanting.

\section{CONFLICT OF INTEREST}

The authors confirm that this article content has no conflict of interest.

\section{ACKNOWLEDGEMENTS}

This work was supported in part by the Auburn University Southern Forest Nursery Management Cooperative and the McIntire Stennis Act.

\section{REFRENCES}

[1] Wakeley PC. Physiological grades of southern pine nursery stock. In: Shirley HL, Ed. Proceedings of the Society of American Foresters; 1948; Boston, Massachusetts: Society of American Foresters; 1949; pp. 311-22.

[2] Wakeley PC. Planting the southern pines. Agricultural Monograph No 18; Washington, D.C.: USDA 1954.

[3] Stone EC. Poor survival and the physiological condition of planting stock. For Sci 1955; 1: 89-94.

[4] Tinus RW. Characteristics of seedlings with high survival potential. In: Tinus RW, Stein WI, Balmer WE, Eds. Proceedings of the North American containerized forest tree seedling symposium; Publ No 68; Denver, Colorodo: Great Plains Ag Council 1974; pp. 276-82

[5] Ritchie GA. Assessing seedling quality. In: Duryea ML, Landis TD, Eds. Forest nursery manual: production of bareroot seedlings. Netherlands: Martinus Nijhoff 1984; pp. 243-66.

[6] Mattsson A. Predicting field performance using seedling quality assessment. New For 1996; 13: 223-48 
[7] Grossnickle SC. Why seedlings survive: importance of plant attributes. New For 2012; 43: 711-38.

[8] Ritchie GA. Some effects of cold storage on seedling physiology. Tree Planters' Notes 1987; 38: 11-5.

[9] Camm EL, Goetze DC, Silim SN, Lavender DP. Cold storage of conifer seedlings: an update from the British Columbia perspective. Forest Chron 1994; 70: 311-6.

[10] McKay HM . A review of the effects of stresses between lifting and planting on nursery stock quality and performance. New For 1997; 13: 369-99.

[11] Colombo SJ, Menzies MI, O'Reilly C. Influence of nursery cultural practices on cold hardiness of coniferous forest tree seedlings. In: Bigras FJ, Colombo SJ, Eds. Conifer cold hardiness. Netherlands: Kluwer Academic Publishers 2001; pp. 223-52.

[12] Landis TD, Dumroese RK, Haase DL. Seedling processing, storage, and outplanting. The container tree nursery manual. Vol. 7. Agricultural Hand book 674. Washington, DC: US Departement of Agricultural Forest Service 2010.

[13] Cleary BD, Greaves RD, Hermann RK, Eds. Regenerating Oregon's forests: a guide for the regeneration forester. Corvallis: OSU Extension Service 1978

[14] Lavender DP, Parish R, Johnson CM, Montgomery G, Vyse A, Willis RA, Winston D, Eds. Regenerating British Columbia's forests. Vancouver: University of British Columbia Press 1990.

[15] Duryea ML, Dougherty PM, Eds. Forest regeneration manual. Dordrecht: Kluwer 1991.

[16] Hobbs SD, Tesch SD, Owston PW, Stewart RE, Tappeiner II JC, Wells GE. Reforestation practices in Southwestern Oregon and Northern California. Corvallis: Forest Research Laboratory, Oregon State University 1992.

[17] Grossnickle SC. Ecophysiology of northern spruce species: the performance of planted seedlings. Ottawa: NRC Research Press 2000.

[18] Wagner B, Colombo SJ, Eds. Regenerating Ontario's Forests. Markham: Fitzhenry \& Whiteside 2001

[19] Grossnickle SC. Importance of root growth in overcoming planting stress. New For 2005; 30: 273-94.

[20] Toumey JW. Seeding and planting. New York: Wiley 1916.

[21] Carlson WC. Lifting, storing, and transporting southern pine seedlings. In: Duryea ML, Dougherty PM, Eds. Forest regeneration manual. Netherlands: Kluwer 1991; pp. 219-301.

[22] Odlum K, Scarratt J, Timmer V, Duckett S, Ross-Slomke P. Container stock production. In: Wagner B, Colombo SJ, Eds. Regenerating Ontario's forests. Markham: Fitzhenry \& Whiteside 2001; pp. 281-306.

[23] Schubert GH, Adams RS. Reforestation Practices for Conifers in California. Sacramento: Departement of Conservation, Division of Forestry 1971.

[24] Garber MP. Effects of chilling and photoperiod on dormancy release of container-grown loblolly pine seedlings. Can J For Res 1983; 13: 1265-70.

[25] Boyer JN, South DB. Dormancy, chilling requirements, and storability of container-grown loblolly pine seedlings. In: South DB, Ed. Proceedings of the IUFRO Symposium on nursery management practices for southern pines 1985; Montgomery, Alabama: Auburn University 1985; pp. 372-83.

[26] Carlson WC. Effects of natural chilling and cold storage on bud break and root growth potential of loblolly pine (Pinus taeda L.). Can J For Res 1985; 15: 651-6.

[27] DeWald LE, Feret PP. Changes in loblolly pine root growth potential from September to April. Can J For Res 1987; 17: 635-43.
[28] Ritchie GA, Roden JR, Kleyn N. Physiological quality of lodgepole pine and interior spruce seedlings: effects of lifting date and duration of freezer storage. Can J For Res 1985; 15: 636-45.

[29] van den Driessche R. Survival of coastal and interior Douglas-fir seedlings after storage at different temperatures, and effectiveness of cold storage to satisfy chilling requirements. Can J For Res 1977; $7: 125-31$.

[30] Timmis R, Flewelling J, Talbert C. Frost injury prediction model for Douglas-fir seedlings in the Pacific Northwest. Tree Physiol 1994; 14: 855-69.

[31] Burdett AN, Simpson DG . Lifting, grading, packaging and storing. In: Duryea ML, Landis TD, Eds. Forest nursery manual: production of bareroot seedlings. Netherlands: Martinus Nijhoff 1984; pp.22734.

[32] Jenkinson JL, Nelson JA, Huddleston ME. Improving planting stock quality - the Humboldt experience. USDA Forest Service Gen Tech Rep 1993; PSW-GTR-143.

[33] Harrington CA, Gould PJ, St. Clair JB. Modeling the effects of winter environment on dormancy release of Douglas-fir. For Ecol Manage 2010; 259: 798-808.

[34] O'Reilly C, McCarthy N, Keane M, Harper CP, Gardiner JJ. The physiological status of Douglas fir seedlings and the field performance of freshly lifted and cold stored stock. Ann For Sci 1999; 56: 297-306.

[35] Carles S, Lamhamedi MS, Stowe DC, Veilleux L, Margolis HA. An operational method for estimating cold tolerance thresholds of white spruce seedlings in forest nurseries. Forest Chron 2012; 88: 448-57.

[36] Fuchigami LH, Weiser CJ, Kobayashi K, Timmis R, Gusta LV. A degree growth stage $\left({ }^{\circ} \mathrm{GS}\right)$ model and cold acclimation in temperate woody plants. In: Li PH, Sakai A, Eds. Plant cold hardiness and freezing stress. New York: Academic Press 1982; pp. 93-116.

[37] Fuchigami LH, Nee CC. Degree growth stage model and restbreaking mechanisms in temperate woody perennials. HortScience 1987; 22: 836-45.

[38] Kramer PJ, Kozlowski TT. Physiology of woody plants. New York: Academic Press 1979.

[39] Ritchie GA, Dunlap JR. Root growth potential: its development and expression in forest tree seedlings. NZ J For Sci 1980; 10: 218 48.

[40] Ritchie GA, Tanaka Y. Root growth potential and the target seedling. In: Rose R., Campbell SJ, Landis TD, Eds. Target seedling symposium. USDA For Serv Gen Tech Rep 1990; RM200; pp.37-51.

[41] Burr KE. The target seedling concept: bud dormancy and coldhardiness. In: Rose R, Campbell SJ, Landis TD, Eds. Target seedling symposium. USDA Forest Service Gen Tech Rep 1990; RM-200: pp.79-90.

[42] Bigras FJ. Conifer bud dormancy and stress resistance: a forestry perspective. In: Lang GE, Ed. Plant dormancy: physiology, biochemistry and molecular biology. Wallingford: $\mathrm{CAB}$ International 1996; pp.171-92.

[43] Weiser CJ. Cold resistance and injury in woody plants. Science 1970; 169: pp.1269-77.

[44] Levitt J. Response of plants to environmental stress. Vol. I. Chilling, freezing and high temperature stress. New York: Academic Press 1980.

[45] Doorenbos J. Review of the literature on dormancy in buds of woody plants. Meded. Landbouwhogesch Wageningen 1953; 53: 124.

[46] Lavender, DP. Measuring phenology and dormancy. In: Lassoie JP, Hinckley TM, Eds. Techniques and approaches in forest tree ecophysiology. Boca Raton: CRC Press 1991; pp.403-22. 
[47] Lang GA, Early JD, Arroyave NJ, Darnell RL, Martin GC, Stutte GW. Dormancy: toward a reduced, universal terminology. HortScience 1985; 20: 809-12.

[48] Perry TO. Dormancy of trees in winter. Science 1971; 171:29-36.

[49] Williams HM, South DB. Effects of fall fertilizer applications on mitotic index and bud dormancy of loblolly pine seedlings. For Sci 1992; 38: 336-49.

[50] Boltz, BA, Bongarten BC, Teskey RO. Seasonal patterns of loblolly pine from diverse origins. Can J For Res 1986; 16: 1063-8.

[51] Cannell, MGR. Physiology of southern pine seedlings. In: South DB, Ed. Proceedings of the IUFRO Symposium on nursery management practices for southern pines; 1985: Montgomery, Alabama: Auburn University 1985; pp. 251-74.

[52] Sung SS, Black CC, Kormanik TL, Zarnoch SJ, Kormanik PP, Counce PA. Fall nitrogen fertilization and the biology of Pinus taeda seedling development. Can J For Res 1997; 27: 1406-12.

[53] Boyer JN, South DB. Seasonal changes in intensity of bud dormancy in loblolly pine seedlings. Tree Physiol 1989; 5: 379-85.

[54] Gagnon KG, Johnson JD. Bud development and dormancy in slash and loblolly pine. I. Speed of budbreak and $2^{\text {nd }}$ year height as related to lifting date. New For 1988; 2: 261-8.

[55] Mexal JG, Timmis R, Morris WG. Cold-hardiness of containerized loblolly pine seedlings. South J Appl For 1979; 3: 15-9.

[56] Hodge GR, Weir RJ. Freeze tolerance of hardy and tender families of loblolly pine. Can J For Res 1993; 23: 1892-9.

[57] Hodge GR, Dvorak WS, Tighe ME. Comparisons between laboratory and field results of frost tolerance of pines from the southern USA and Mesoamerica planted as exotics. South For 2012; 74: 7-17.

[58] DeWald LE, Feret PP, Kreh RE. A 15-day hydroponic system for measuring root growth potential. USDA For Serv GTR 1985; SO54: pp.4-10.

[59] Freyman RC, Feret PP, DeWald LE. Variation in loblolly pine seedling root growth potential over two lifting seasons. In: Lantz CW, Ed. National Nursery Proceedings. Pensacola, Florida; Southern Forest Nursery Association 1986; pp. 224-31.

[60] Williams HM, South DB, Glover GR. Effect of bud status and seedling biomass on root growth potential of loblolly pine. Can J For Res 1988; 18: 1635-40.

[61] Feret PP, Freyman RC, Kreh RE. Variation in root growth potential of loblolly pine from seven nurseries. In: South DB, Ed. Proceedings of the IUFRO Symposium on nursery management practices for southern pines 1985; Montgomery, Alabama: Auburn University 1985; pp. 317-28.

[62] Lavender DP. Plant physiology and nursery environment: Interactions affecting seedling growth. In: Duryea ML, Landis TD, Eds. Forest nursery manual: production of bareroot seedlings. Netherlands: Martinus Nijhoff 1984; pp.133-41.

[63] Cannell MGR, Tabbush PM, Deans JD, et al. Sitka spruce and Douglas fir seedlings in the nursery and in cold storage: root growth potential, carbohydrate content, dormancy, frost hardiness and mitotic index. Forest 1990; 63: 8-27.

[64] MacDonald JE, Owens JN. Physiology and growth of containerized coastal Douglas fir seedlings given different durations of short days to induce dormancy. HortScience 2010; 45: 342-6.

[65] Lavender DP. Bud dormancy. In: Duryea ML, Ed. Evaluating seedling quality: principles, procedures, and predictive ability of major tests. Corvallis: Forest Research Laboratory, Oregon State University 1985 ; pp.7-15.

[66] Lavender DP, Cleary BD. Coniferous seedling production techniques to improve seedling establishment. In: Tinus RW, Stein WI, Balmer WE, Eds. Proceedings of the North American containerized forest tree seedling symposium; Publ No 68 Denver, Colorodo: Great Plains Ag Council 1974; pp. 177-80.

[67] Ritchie GA, Shula RG. Seasonal changes of tissue-water relations in shoots and root systems of Douglas-fir seedlings. For Sci 1984; 2: $538-48$.

[68] Timmis R, Worrall J. Environmental control of cold acclimation in Douglas-fir during germination, active growth, and rest. Can J For Res 1975; 5: 464-77.

[69] Sweet GB. Provenance differences in Pacific coast Douglas-fir. Silvae Genet 1965; 14: 46-56.

[70] Campbell RK, Sugano AI. Phenology and bud burst in Douglas-fir related to provenance, photoperiod, chilling, and flushing temperature. Bot Gaz 1975; 136: 290-8.

[71] Campbell RK, Sugano AI. Genecology of bud-burst phenology in Douglas-fir: response to flushing temperature and chilling. Bot Gaz 1979; 140: 223-31.

[72] Wommack DE. Temperature effects on the growth of Douglas-fir seedlings. Dissertation, Oregon State University; 1964 [cited 20 Dec 2013]; Available from: http://hdl.handle.net/1957/10404

[73] Ritchie GA. Some effects of cold storage on seedling physiology. In: Landis TD, Ed. Proceedings of the Combined Western Forest Nursery Council and Intermountain Nursery Association Meeting: USDA For Serv Gen Tech Rep; RM-137:1986; pp.57-61.

[74] Ritchie GA, Tanaka Y, Duke SD. Physiology and morphology of Douglas-fir rooted cuttings compared to seedlings and transplants. Tree Physiol 1992; 10: 179-94.

[75] Guak S, Olsyzk DM, Fuchigami LH, Tingey DA. Effects of elevated $\mathrm{CO}_{2}$ and temperature on cold hardiness and spring bud burst and growth in Douglas-fir (Pseudotsuga menziesii). Tree Physiol 1998; 18: 671-9.

[76] Aitken SN, Hannerz M. Genecology and gene resource management strategies for conifer cold hardiness. In: Bigras, FJ, Colombo SJ, Eds. Conifer Cold Hardiness. Netherlands: Kluwer 2001: 23-53.

[77] Winjum JK. Effects of lift date and storage of 2+0 Douglas-fir and Noble fir. J For 1963; 61: 648-54.

[78] Ritchie GA. Effect of freezer storage on bud dormancy release in Douglas-fir seedlings. Can J For Res 1984; 14: 186-90.

[79] McKay HM, Mason WL. Physiological indicators of tolerance to cold storage in Sitka spruce and Douglas-fir seedlings. Can J For Res 1991; 21: 890-901.

[80] Owens JN, Molder M, Langer H. Bud development in Picea glauca. I. Annual growth cycle of vegetative buds and shoot elongation as they relate to date and temperature sums. Can J Bot 1977; 55: 2728-45.

[81] Harrison DLS, Owens JN. Bud development in Picea engelmannii. I. Vegetative bud development, differentiation, and early development of reproductive buds. Can J Bot 1983; 61: 2291-301.

[82] Colombo SJ, Webb DP, Glerum C. Cold hardiness and bud development under short days in black spruce and white spruce seedlings. In: Scarratt JB, Glerum, Plexman CA, Eds. Proceedings of the Canadian containerized tree seedling symposium. Symp Proc O-P-10: 1982. Toronto, Ontario: COJFRC; pp. 171-6.

[83] Pollard DFW. Bud morphogenesis of white spruce Picea glauca seedlings in a uniform environment. Can J Bot 1974; 52: 1569-71.

[84] Owens JN, Molder M. Bud development in Picea glauca. II. Cone differentiation and early development. Can J Bot 1977; 55: 274660 .

[85] Grossnickle SC, Sutton BCS, Folk RS, Gawley BJ. Relationship between nuclear DNA markers and physiological parameters for Sitka x interior spruce populations. Tree Physiol 1996; 16: 547-55. 
[86] Johnson-Flanagan AM, Owens JN. Root growth and root growth capacity of white spruce (Picea glauca [Moench] Voss) seedlings. Can J For Res 1985; 15: 625-30.

[87] Burr KE, Tinus RW, Wallner SJ, King RM. Relationships among cold hardiness, root growth potential and bud dormancy in three conifers. Tree Physiol 1989; 5: 291-306.

[88] Nienstaedt H. Chilling requirements in seven Picea species. Silvae Genet 1967; 16: 65-8.

[89] Grossnickle SC. Shoot phenology and water relations of Picea glauca. Can J For Res 1989; 19: 1287-90.

[90] Glerum C. Annual trends in frost hardiness and electrical impedance for seven coniferous species. Can J Plant Sci 1973; 53: 881-9.

[91] Burr KE, Tinus RW, Wallner SJ, King RM. Comparison of three cold hardiness tests for conifer seedlings. Tree Physiol 1990; 6: 351-69.

[92] Bigras FJ, D'Aoust AL. Influence of photoperiod on shoot and root frost tolerance and bud phenology of white spruce seedlings (Picea glauca). Can J For Res 1993; 23: 219-28.

[93] Binnie SC, Grossnickle SC, Roberts DR. Fall acclimation patterns of interior spruce seedlings and their relationship to changes in vegetative storage proteins. Tree Physiol 1994; 14: 1107-20.

[94] Colombo SJ, Teng Y. Seasonal variation in water relations of white spruce seedlings. Oecologia 1992; 92: 410-5.

[95] Tinus RW, McDonald SE. How to grow tree seedlings in containers in greenhouses. USDA For Serv Gen Tech Rep 1979; RM-60.

[96] Landis TD, Tinus RW, Barnett JP. Seedling propagation. The container tree nursery manual, Vol. 6. Agricultural Hand Boook. Washington, D.C.: Department of Agricultural Forest Service 1999.

[97] Landis TD, Tinus RW, McDonald SE, Barnett JP. Seedling nutrition and irrigation. The container tree nursery manual. Vol. 4. Agricultural Hand Book. Washington, D.C.: Department of Agricultural Forest Service 1989.

[98] Duryea ML. Nursery cultural practices: impacts on seedling quality. In: Duryea ML, Landis TD, Eds. Forest nursery manual: production of bareroot seedlings. Netherlands: Martinus Nijhoff 1984; pp.143-64.

[99] Lantz CW, Ed. Southern Pine Nursery Handbook. Atlanta: USDA Forest Service Cooperative Forestry, Southern Region 1985.

[100] Mexal JG, South DB. Bareroot seedling culture. In: Duryea ML, Dougherty PM, Eds. Forest regeneration manual. Netherlands: Kluwer 1991; pp. 89-115.

[101] South DB. Needle-clipping longleaf pine and top-pruning loblolly pine in bareroot nurseries. South J Appl For 1998; 22: pp. 235-40.

[102] Williams HM, South DB, Webb A. Effect of fall irrigation on morphology and root growth potential of loblolly pine seedlings growing in sand. South Afr For J 1988; 147: 1-5.

[103] Cleary BD, Greaves RD, Owsten PW. Seedlings. In: Cleary BD, Greaves RD, Hermann RK, Eds. Regenerating Oregon's forests: a guide for the regeneration forester. Corvalis: OSU Extension Service 1978; 63-97.

[104] Macey DE, Arnott JT. The effect of moderate moisture and nutrient stress on bud formation and growth of container-grown white spruce seedlings. Can J For Res 1986; 16: 949-54.

[105] Calmé S, Margolis HA, Bigras FJ. Influence of cultural practices on the relationship between frost tolerance and water content of containerized black spruce, white spruce, and jack pine seedlings. Can J For Res 1993; 23: 503-11.

[106] MacDonald JE, Owens JN. Morphology, physiology, survival, and field performance of containerized coastal Douglas fir seedlings given different dormancy-induction regimes. HortScience 2006; 41: $1416-20$

[107] Barnette JP, Brissette JC. Producing southern pine seedlings in containers. USDA Forest Service Tech Rep 1986; SO-59.

[108] Brissette JC, Barnett JP, Landis TD. Container seedlings. In: Duryea ML, Dougherty PM, Eds. Forest regeneration manual. Netherlands: Kluwer 1991; pp.117-41.

[109] Timmis R, Tanaka Y. Effects of container density and plant water stress on growth and cold hardiness of Douglas-fir seedlings. For Sci 1976; 22: 167-72.

[110] Timmer VR. Exponential nutrient loading: a new fertilization technique to improve seedling performance on competitive sites. New For 1997; 13: 279-99.

[111] Benzian B. Effects of nitrogen and potassium concentrations in conifer seedlings on frost damage. Rep Forest Res for 1966. London: Forestry Commission 1967.

[112] Pumpel B, Gobi F, Tranquillini W. Wachstum, Mykorrhiza and Frostresistenz von Fichtenjungpflanzen bei Dungung mit Verschiedenen Stickstoffgaben. Eur J For Pathol 1975; 5: 83.

[113] DeHayes DH, Ingle MA, Waite CE. Nitrogen fertilization enhances cold tolerance of red spruce seedlings. Can J For Res 1989; 19: 1037-43.

[114] Klein RM, Perkins TF, Meyers HL. Nutrient status and winter hardiness of red spruce foliage. Can J For Res 1989; 19: 754-8.

[115] L'Hirondelle SJ, Jacobson JS, Lassoie JP. Acidic mist and nitrogen fertilization effects on growth, nitrate reductase activity, gas exchange, and frost hardiness of red spruce seedlings. New Phytol 1992; 121: 611-22.

[116] Timmis R. Effect of nutrient stress on growth, bud set, and hardiness in Douglas-fir seedlings. In: Tinus RW, Stein WI, Balmer WE, Eds. Proceedings of the North American containerized forest tree seedling symposium; Publ No 68: Denver, Colorodo: Great Plains Agricultural Council 1974; pp. 187-93.

[117] Dumroese RK. Hardening fertilization and nutrient loading of conifer seedlings. In: Riley LE, Dumroese RK, Landis TD, Eds. National proceeding of the: forest and conservation nursery associations 2002. USDA For Serv Gen Tech Rep 2002; RMRS-P28: pp.31-6.

[118] Edwards IK. The effects of mineral nutrition on hardening-off of conifer seedlings. In: Landis TD, Ed. Proceedings, intermountain forest nursery association; 1989. USDA For Serv Gen Tech Rep 1989; RM-184: pp.98-102.

[119] Redfern DB, Cannell MGR. Needle damage in Sitka spruce caused by early autumn frosts. Forest 1982; 55: 39-46.

[120] Brix, H, van den Driessche R. Mineral nutrition of container-grown tree seedlings. In: Tinus RW, Stein WI, Balmer WE, Eds. Proceedings of the North American containerized forest tree seedling symposium; Publ No 68; Denver, Colorodo: Great Plains Agricultural Council 1974; pp. 77-84.

[121] van den Driessche, R. Effects of nutrients on stock performance in the forest. In: van den Driessche, R, Ed. Mineral nutrition of conifer seedlings, Boca Raton: CRC Press 1991; pp. 229-60.

[122] South DB, Donald DG. Effect of nursery conditioning treatments and fall fertilization on survival and early growth of Pinus taeda seedlings in Alabama, USA. Can J For Res 2002; 32: 1171-9.

[123] Lavender DP, Wareing PF. The effects of daylength and chilling on the response of Douglas-fir (Pseudotsuga menziesii (Mirb) Franco) seedlings to root damage and storage. New Phytol 1972; 71: 105567.

[124] Williams BJ, Pellett NE, Klein RM. Phytochrome control of growth cessation and initiation of cold acclimation in selected woody plants. Plant Physiol 1972; 50: 262-5. 
[125] van den Driessche R. Influence of moisture supply, temperature, and light on frost hardiness changes in Douglas-fir seedlings. Can J Bot 1969; 47: 1765-72.

[126] Lavender DP, Stafford SG. Douglas-fir seedlings: some factors affecting chilling requirements, bud activity, and new foliage production. Can J For Res 1985; 15: 309-12.

[127] Arnott JT, Mitchell A. Influence of extended photoperiod on growth of white and Engelmann spruce seedlings in coastal British Columbia nurseries. In: Scarratt JB, Glerum, Plexman CA, Eds. Proceedings of the Canadian Containerized Tree Seedling Symposium. Toronto, Ontario: COJFRC Symp Proc O-P-10; 1982; pp. 139-52.

[128] Coursolle C, Bigras FJ, Margolis HA, Hébert C. Growth and hardening of four provenances of containerized white spruce (Picea glauca (Moench) Voss) seedlings in response to the duration of $16 \mathrm{~h}$ long-night treatments. New For 1998; 16: 155-66.

[129] Kramer PJ. Effect of variation in length of day on growth and dormancy of trees. Plant Physiol 1936; 11: 127-37.

[130] South DB, Donald DGM, Rakestraw JL. Effect of nursery culture and bud status on freeze injury to Pinus taeda and $P$ elliottii seedlings. South Afr For J 1993; 166: 37-45.

[131] Duryea ML, Omi SK. Top pruning Douglas-fir seedlings: morphology, physiology and field performance. Can J For Res 1987; 17: 1371-8

[132] Mohammed GH, McLeod GR, Menes PA, Timmer VR. Bareroot stock production. In: Wagner B, Colombo SJ, Eds. Regenerating the Canadian Forests. Markham, Ont. Fitzhenry \& Whiteside Ltd 2001; pp 265-79.

[133] Tanaka Y, Walstad JD, Borrecco JE. The effect of wrenching on morphology and field performance of Douglas fir and loblolly pine seedlings. Can J For Res 1976; 6: 453-8.

[134] Racey GD. Cold temperature conditioning of conifer seedlings prior to frozen overwinter storage. Forest Research report 118. Maple: Ontario Ministry of Natural Resources 1988.

[135] Ritchie GA. Integrated growing schedules for achieving physiological uniformity in coniferous planting stock. For Suppl 1989; 62: 213-27.

[136] Dumroese RK, Barnett J. Container seedling handling and storage in the southeastern states. In: Riley LE, Dumroese RK, Landis TD, Eds. National proceedings of the Forest and Conservation Nursery Associations 2004. USDA For Serv Gen Tech Rep 2004; RMRS-P33: pp. 22-5.

[137] Stumpff NJ, South DB. Benomyl root dips adversely affect firstyear performance of stored loblolly pine seed lings. South J Appl For 1991; 15: 133-7.

[138] May JT. Packing, storage and shipping. In: Lantz CW, Ed. Southern Pine Nursery Handbook. Atlanta: USDA For Serv Coop Forestry, Southern Region 1985: pp. 100-12.

[139] Ritchie GA. Container seedling storage and handling in the Pacific Northwest: answers to some frequently asked questions. In: Riley LE, Dumroese RK, Landis TD, Eds. USDA For Serv Gen Tech Rep 2004; RMRS-P-33: pp. 3-7.

[140] Burr KE, Hawkins CDB, L'Hirondelle SJ, Binder WD, George MF, Repo T. Methods for measuring cold hardiness of conifers. In: Bigras F, Colombo S, Eds. Conifer cold hardiness. Netherlands: Kluwer 2001; pp.369-401.

[141] Tung CH, Wisniewski L, DeYoe DR. Effects of prolonged cold storage on phenology and performance of Douglas-fir and noble fir $2+0$ seedlings from high elevation sources. Can J For Res 1986; 16: $471-5$.

[142] Kooistra CM. Seedling storage and handling in western Canada. In: Riley LE, Dumroese RK, Landis TD, Eds. National proceedings: Forest and Conservation Nursery Associations 2002. USDA of the Serv Gen Tech Rep 2004; RMRS-P-33: pp. 15-21.
[143] Grossnickle SC, Major JE, Folk RS. Interior spruce seedlings compared to emblings produced from somatic embryogenesis. I) Nursery development, fall acclimation and over-winter storage. Can J For Res 1994; 24: 1376-84.

[144] Simpson DG. Frost hardiness, root growth capacity, and field performance relationships in interior spruce, lodgepole pine, Douglas-fir, and western hemlock seedlings. Can J For Res 1990; 20: 566-72.

[145] L'Hirondelle SJ, Simpson DG, Binder WD. Overwinter storability of conifer planting stock: operational testing of fall frost hardiness. New For 2006; 32: 307-21.

[146] Colombo SJ. Frost hardening spruce container stock for overwintering in Ontario. New For 1997. 13; 449-67.

[147] Hodges CS. Freezing lowers survival of three species of southern pines. Tree Planters' Notes 1961; 47: 23-4.

[148] Garner JW, Dierauf TA. Effect of freezing on survival of loblolly pine seedlings. Charlottesville: VA Div For 1974; Occ Rep 44. [cited: 20 Dec 2013]; Available from: http://www.dof.virginia.gov/-print/research/archive/report-0044.pdf

[149] van Eerden E, Gates JW. Seedling production and processing: containers. In: Lavender DP, Parish R, Johnson CM, Montgomery G, Vyse A, Willis RA, Winston D, Eds. Regenerating British Columbia's Forests. Vancouver: University of British Columbia Press 1990; pp. 226-34.

[150] Mitchell WK, Dunsworth G, Simpson DG, Vyse A. Planting and seeding. In: Lavender D.P., Paris R, Johnson C.M, et al. Montomery G., Vyse A. Willis R.A. and Winston D, Eds. Regenerating British Columbia's Forests. Vancouver: University of British Columbia Press 1990; pp.235-53.

[151] Hee SM. Freezer storage practices at Weyerhaeuser nurseries. Tree Planters' Notes 1987; 38(2): 7-10.

[152] Perks MP, Monaghan S, O'Reilly C, Osbornea BA, Mitchell DT. Chlorophyll fluorescence characteristics, performance and survival of freshly lifted and cold stored Douglas fir seedlings. Ann For Sci 2001; 58: 225-35.

[153] Jacobs DF, Davis AS, Wilson BC, Dumroese RK, Goodman RC, Salifu KF. Short-day treatment alters Douglas-fir seedling dehardening and transplant root proliferation at varying rhizosphere temperatures. Can J For Res 2008; 38: 1526-35.

[154] Timmis R. Frost hardening of containerized conifer seedlings under constant and sequenced temperatures. Centralia; Tech Rep 0422201/78/37. Weyerhaeuser: Forest Research 1978.

[155] McKay HM. Frost hardiness and cold storage tolerance of the root systems of Picea sitchensis, Pseudotsuga menziesii, Larix kaempferi and Pinus sylvestris bare-root seedlings. Scand J For Res 1994; 9: 203-13.

[156] Ritchie GA. A rapid method for detecting cold injury in conifer seedling root systems. Can J For Res 1990; 20: 26-30.

[157] Grossnickle SC, Folk RS. Spring versus summer spruce stock types of western Canada: nursery development and field performance. West J Appl For 2003; 18: 267-75.

[158] Wang Y, Zwiazek J. Effects of storage temperature on physiological characteristics of fall-lifted white spruce (Picea glauca) bareroot seedlings. Can J For Res 1999; 29: 679-86.

[159] Hocking D. Effect of characteristics of pathogens on foliage and buds of cold-stored white spruce and lodgepole pine seedlings. Can J For Res 1971; 1: 208-15.

[160] Hocking D, Nyland RD. Cold storage of coniferous seedlings. Rep 6. Syracuse: Applied Forest Research Institute, State University College of Forestry 1971.

[161] Sakai A, Larcher W. Frost survival of plants. Responses and adaptation to freezing stress: ecological studies Vol. 62. New York: Springer-Verlag; 1987. 
[162] Ursic SJ, Williston HL, Burns RM. Late planting improves loblolly survival. USDA For Serv Res Paper 1966; SO-24.

[163] Kahler LH, Gilmore AR. Field survival of cold stored loblolly pine seedlings. Tree Planters' Notes 1961 45: 15-6.

[164] Dierauf TA. Effect of time of lifting and length of time in cold storage on survival and growth of loblolly pine seedlings. Charlottesville: Virginia Division of For 1974; [cited: 20 Dec 2013]. Available from: http://www.dof.virginia.gov/print/research/archive/report-0043.pdf

[165] Garber MP, Mexal JG. Lift and storage practices: their impact on successful establishment of southern pine plantations. NZ J For Sci 1980; 10: 72-82.

[166] Williston HL. Storage of southern pine seedlings: a review. Tree Planters' Notes 1974; 25: 1-3.

[167] Jackson DP, Enebak SA, South DB. Pythium species and cold storage affect the root growth potential and survival of loblolly (Pinus taeda L.) and slash pine (Pinus elliottii Engelm.) seedlings. J Hort For 2012; 4: 114-9.

[168] Mohammed GH, McLeod GR, Menes PA, Timmer VR. A comparison of bareroot and container stock. In: Wagner B, Colombo SJ Eds. Regenerating Ontario's Forests. Markham: Fitzhenry \& Whiteside 2001; pp.343-8.

[169] VanderSchaaf C, McNabb K. Winter nitrogen fertilization of loblolly pine seedlings. Plant Soil 2004; 265: 295-9.

[170] Barnett JP, Brissette JC, Kais AG, Jones JP. Improving field performance of southern pine seedlings by treating with fungicides before storage. South J Appl For 1988; 12: 281-5.

[171] Hallgren SW, Ferris DM. Benomyl applied to roots improves second-year survival and growth of shortleaf pine. South J Appl For 1995; 19: 36-41.

[172] Brissette JC, Barnett JP, Jones JP. Fungicides improve field performance of stored loblolly and longleaf pine seedlings. South J Appl For 1996; 20: 5-9.

[173] van West PV, Morris BM, Reid B, Appiah AA, Osborne MC, Campbell TA, Shephard SJ, Gow NAR. Oomycete plant pathogens use electric fields to target roots. Mol Plant-Microbe Interact 2002; 15: $790-8$.

[174] Turner J, Mitchell SJ. The effect of short day treatments on containerized Douglas-fir morphology, physiology and phenology. New For 2003; 26: 279-95.

[175] van den Driessche R. Measurement of frost hardiness in two-year old Douglas-fir seedlings. Can J Plant Sci 1969; 49: 159-72.

[176] Ritchie GA. Carbohydrate reserves and root growth potential in Douglas-fir seedlings before and after cold storage. Can J For Res 1982; 12: 905-12.

[177] Hildebrand DM. Viability of 1+1 Douglas-fir transplants when held in cold or frozen storage. USDA Forest Service PNW Region 1996; R6-96-02.

[178] McKay HM. Tolerance of conifer fine roots to cold-storage. Can J For Res 1993; 23: 337-42.

[179] Chomba BM, Guy RD, Weger HG. Carbohydrate reserve accumulation and depletion in Engelmann spruce (Picea engelmannii): effects of cold storage and pre-storage $\mathrm{CO}_{2}$ enrichment. Tree Physiol 1993; 13: 351-64.

[180] Camm EL, Harper GJ. Temporal variations in cold sensitivity of root growth in cold-stored white spruce seedlings. Tree Physiol 1991; 9: 425-31.

[181] Marshall JD. Carbohydrate status as a measure of seedling quality. In: Duryea ML, Ed. Evaluating seedling quality: principles, procedures, and predictive ability of major tests. Corvallis: Forest Research Laboratory, Oregon State University 1985; pp. 49-58.
[182] Luoranen J, Riikonen J, Rikala R, Sutinen S. Frost hardiness, carbohydrates and bud morphology of Picea abies seedlings after different lengths of freezer storage. Scand J For Res 2012; 27: 4149.

[183] Kim YT, Glerum C, Hickie DF, Chen CP. Effects of cold storage duration on carbohydrate and amino acid concentration, root growth for potential, and growth of jack pine and black spruce seedlings. Res Rep 143. Sault Ste Marie: Ontario Forest Research Institute 1997.

[184] Jiang Y, Zwiazek JJ, MacDonald SE. Effects of prolonged cold storage on carbohydrate and protein content and field performance of white spruce bareroot seedlings. Can J For Res 1994; 24: 1369. 75 .

[185] Wang Y, Zwiazek J. Effects of early spring photosynthesis on carbohydrate content, bud flushing, and root and shoot growth of Picea glauca bareroot seedlings. Scand J For Res 1999; 14: 295302.

[186] Lindström A, Stattin E. Root freezing tolerance and vitality of Norway spruce and Scots pine seedlings: influence of storage duration, storage temperature, and prestorage root freezing. Can J For Res 1994; 24: 2477-84.

[187] Ögren E. Relationship between temperature, respiratory loss of sugar and premature dehardening in dormant Scots pine seedlings. Tree Physiol 1997; 17: 47-51.

[188] Ögren E, Nilsson T, Sundblad LG. Relationship between respiratory depletion of sugars and loss of cold hardiness in coniferous seedlings over-wintering at raised temperatures: indications of different sensitivities of spruce and pine. Plant Cell Environ 1997; 20: 247-53.

[189] van den Driessche R. Respiration rate of cold-stored nursery stock. Can J Forest Res 1979; 9: 15-8.

[190] Deans JD, Lundberg C, Tabbush PM, Cannall MGR, Sheppard LJ, Murray MB. The influence of desiccation, rough handling and cold storage on the quality and establishment of Sitka spruce planting stock. Forest 1990; 63: 129-41.

[191] Colombo SJ. Bud dormancy status, frost hardiness, shoot moisture content, and readiness of black spruce container seedlings for frozen storage. J Am Soc Hortic Sci 1990; 115: 302-7.

[192] Lefevre RE, Cameron AC, Peterson NC. Influence of moisture loss during storage on new growth of conifer seedlings. J Environ Hort 1991; 9: 92-6.

[193] Rowe SJ. Environmental preconditioning with special reference to forestry. Ecology 1964; 45: 399-403.

[194] Hobbs SD. The influence of species and stocktype selection on stand establishment: An ecophysiological perspective. In: Duryea ML, Brown GH, Eds. Seedling physiology and reforestation success. Boston: Martinus Nijhoff 1984; pp.180-224.

[195] Donald DGM. The use of open-rooted pine seedlings for afforestation in South Africa. S Afr For J 1976; 97: 1-11.

[196] McGill DW, Bridge ET. Growing season effects on 5-year growth of loblolly pine near Parkersburg, West Virginia. In: Waldrop TA, Ed. Proceedings of the $9^{\text {th }}$ biennial southern silvicultural research conference. USDA Forest Service Gen Tech Rep 1998; SRS-20: pp.333-7.

[197] South DB. Freeze injury to roots of southern pine seedlings in the USA. South Hemi For J 2007; 69: 151-6.

[198] Hermann RK. Seasonal variation in sensitivity of Douglas-fir seedlings to exposure of roots. For Sci 1967; 13: 140-9.

[199] van den Driessche R, Cheung KW. Relationship of stem electrical impedance and water potential of Douglas-fir seedlings to survival after cold storage. For Sci 1979; 25: 507-17.

[200] Lavender DP. Date of lifting for survival of Douglas-fir seedlings. Corvallis: Oregon State Univ For Res Lab 1964; Res. Note 49. 
[cited: 20 Dec 2013]. Available from: http://ir.library.oregonstate. edu/xmlui/handle/1957/8096

[201] Fraser B, Haywood-Farmer S, Kooistra C. Thawing guidelines for frozen stock. In: Scagel R, Evans R, Eds. Consumer's guide to tree seedlings. A workbook on production, testing and handling. Victoria: Canada - British Columbia Forest Resource Development Agreement 1990; pp. 61-4.

[202] Kooistra CM, Bakker JD. Planting frozen conifer seedlings: warming trends and effects on seedling performance. New For 2002; 23: 225-37.

[203] Rose R, Haase D. Thawing regimes for freezer-stored container stock. Tree Planters' Notes 1997; 48: 12-8.

[204] Silim SN, Guy RD. Influence of thawing duration on performance of conifer seedlings. In: Kooistra CM, Ed. Proceedings of the 1995, 1996, and 1997 Annual Meetings of the Forest Nursery Association BC. Vernon: Forest Nursery Association of BC 1997; pp. 155-62.

[205] Kooistra CM, Bakker JD. Planting frozen conifer seedlings. In: Gertzen D, van Steenis E, Trotter D, Kolotelo D, Summers D, Tech Coord. Proceedings of the $19^{\text {th }}$ annual meeting of the forest nursery association BC. Surrey: BC Ministry of Forestry 1999; pp.87-9.

[206] Camm EL, Guy RD, Kubien DS, Goetze DC, Silim SN, Burton PJ. Physiological recovery of freezer-stored white and Engelmann spruce seedlings planted following different thawing regimes. New For 1995; 10: 55-77.

[207] Kooistra CM, Bakker JD. Frozen-stored conifer container stock can be outplanted without thawing. Native Plants J 2005; 6: 267-78.

[208] Helenius P. Effect of thawing regime on growth and mortality of frozen-stored Norway spruce container seedlings planted in cold and warm soil. New For 2005; 29: 33-41.
[209] Wenny DL, Swanson DJ, Dumroese RK. The chilling optimum of Idaho and Arizona ponderosa pine buds. West J Appl For 2002; 17: $117-21$.

[210] Grossnickle SC, Blake TJ. Acclimation of cold-stored jack pine and white spruce seedlings: effect of soil temperature on water relation patterns. Can J For Res 1985; 15: 544-50.

[211] Harper GJ, Camm EL. Effects of frozen storage duration and soil temperature on the stomatal conductance and net photosynthesis of Picea glauca seedlings. Can J For Res 1993; 23: 2459-66.

[212] Camm EL, Harper GJ, Rosenthal SI, Camm DM. Effect of photon flux density on carbon assimilation and chlorophyll a fluorescence of cold-stored white spruce and lodgepole pine seedlings. Tree Physiol 1993; 12: 185-94.

[213] Jiang Y, MacDonald SE, Zwiazek JJ. Effects of cold storage and water stress on water relations and gas exchange of white spruce (Picea glauca) seedlings. Tree Physiol 1995; 15: 267-73.

[214] Islam MA, Apostol KG, Jacobs DF, Dumroese RK. Physiological responses of planting frozen and thawed Douglas-fir seedlings. In: Dumroese RK, Riley LE, Eds. National proceedings of the Forest and Conservation Nursery Associations 2007. USDA For Serv Gen Tech Rep 2008; RMRS-P-57: pp. 126-34.

[215] Islam MA, Jacobs DF, Apostol KG, Dumroese RK. Transient physiological responses of planting frozen root plugs of Douglas-fir seedlings. Can J For Res 2008; 38: 1517-25.

[216] Bigras FJ, Ryyppo A, Linderstrom A, Stattin E. Cold acclimation and deacclimation of shoots and roots of conifer seedlings. In: Bigras FJ, Colombo SJ, Eds. Conifer cold hardiness. Netherlands: Kluwer 2001; pp.57-88.

[217] Bigras FJ, Dumais D. Root-freezing damage in the containerized nursery: impact on plantation site - a review. New For 2005; 30: $167-84$. 